\title{
Article \\ Climate Change Impacts on Groundwater Recharge in Cold and Humid Climates: Controlling Processes and Thresholds
}

\author{
Emmanuel Dubois ${ }^{1,2,3, * \mathbb{C}}$, Marie Larocque ${ }^{1,2,3}$, Sylvain Gagné ${ }^{1,2}$ and Marco Braun ${ }^{4}$ \\ 1 Département des Sciences de la Terre et de l'atmosphère, Université du Québec à Montréal, Pavillon \\ Président-Kennedy, C.P. 8888, Succursale Centre-Ville, Montréal, QC H3C 3P8, Canada; \\ larocque.marie@uqam.ca (M.L.); gagne.sylvain@uqam.ca (S.G.) \\ 2 GEOTOP Research Center, Université du Québec à Montréal, Pavillon Président-Kennedy, C.P. 8888, \\ Succursale Centre-Ville, Montréal, QC H3C 3P8, Canada \\ 3 GRIL Research Center, Département de Sciences Biologiques, Université de Montréal, Campus MIL, C.P. 6128, \\ Succ. Centre-Ville, Montréal, QC H3C 3J7, Canada \\ 4 Ouranos, 550 Rue Sherbrooke Ouest, Tour Ouest, 19e étage, Montréal, QC H3A 1B9, Canada; \\ Braun.Marco@ouranos.ca \\ * Correspondence: dubois.emmanuel@courrier.uqam.ca
}

check for

updates

Citation: Dubois, E.; Larocque, M.;

Gagné, S.; Braun, M. Climate Change Impacts on Groundwater Recharge in Cold and Humid Climates:

Controlling Processes and

Thresholds. Climate 2022, 10, 6 .

https://doi.org/10.3390/cli10010006

Academic Editors:

Mohammad Valipour, Sayed

M. Bateni and Ying Ouyang

Received: 15 November 2021

Accepted: 4 January 2022

Published: 12 January 2022

Publisher's Note: MDPI stays neutral with regard to jurisdictional claims in published maps and institutional affiliations.

Copyright: (C) 2022 by the authors. Licensee MDPI, Basel, Switzerland. This article is an open access article distributed under the terms and conditions of the Creative Commons Attribution (CC BY) license (https:// creativecommons.org/licenses/by/ $4.0 /)$.

\begin{abstract}
Long-term changes in precipitation and temperature indirectly impact aquifers through groundwater recharge (GWR). Although estimates of future GWR are needed for water resource management, they are uncertain in cold and humid climates due to the wide range in possible future climatic conditions. This work aims to (1) simulate the impacts of climate change on regional GWR for a cold and humid climate and (2) identify precipitation and temperature changes leading to significant long-term changes in GWR. Spatially distributed GWR is simulated in a case study for the southern Province of Quebec (Canada, 36,000 $\mathrm{km}^{2}$ ) using a water budget model. Climate scenarios from global climate models indicate warming temperatures and wetter conditions (RCP4.5 and RCP8.5; 1951-2100). The results show that annual precipitation increases of $>+150 \mathrm{~mm} / \mathrm{yr}$ or winter precipitation increases of $>+25 \mathrm{~mm}$ will lead to significantly higher GWR. GWR is expected to decrease if the precipitation changes are lower than these thresholds. Significant GWR changes are produced only when the temperature change exceeds $+2{ }^{\circ} \mathrm{C}$. Temperature changes of $>+4.5^{\circ} \mathrm{C}$ limit the GWR increase to $+30 \mathrm{~mm} / \mathrm{yr}$. This work provides useful insights into the regional assessment of future GWR in cold and humid climates, thus helping in planning decisions as climate change unfolds. The results are expected to be comparable to those in other regions with similar climates in post-glacial geological environments and future climate change conditions.
\end{abstract}

Keywords: groundwater recharge; climate change; thresholds; seasonality; spatiotemporal variations; regional-scale; long-term; HydroBudget model; cold and humid climates; Quebec (Canada)

\section{Introduction}

Climate change is already impacting the water cycle everywhere around the world because of precipitation changes and warming temperatures [1]. In particular, it is impacting surface water and groundwater systems in cold and humid climates due to high rates of precipitation change and warming temperatures [2-5]. Because changes at the surface propagate to aquifers through groundwater recharge (GWR), they could have major impacts on groundwater use for human consumption, industry, and agriculture, as well as on groundwater-dependent ecosystems [6-10]. Although the impacts of climate change on groundwater are increasingly studied, the uncertainty associated with simulations of future climatic conditions remains high [9,11-14]. This is even more remarkable in cold and humid climates, where precipitation changes are uncertain (increase or decrease) and where seasonal snow coverage, which leads the annual hydrological cycle, is particularly sensitive to cold season temperatures [2]. A literature review of climate change impacts on 
groundwater systems in eastern Canada highlighted the wide variability of simulation results from 22 studies spanning the Canadian provinces of Ontario, Quebec, New Brunswick, Nova Scotia, and Prince Edward Island [15]. Using different hydrological, hydrogeological, or integrated models, different downscaling techniques, or different time horizons thus adds further uncertainty to the analysis [15-17], making it difficult to compare future outlooks. Nevertheless, simulation of future conditions remains an essential tool for long-term groundwater resource management in a climate change context.

In cold and humid regions, the geomorphology has largely been shaped by the latest glaciation cycle, groundwater levels are often close to the surface, and unconfined aquifers are generally fed through GWR and connected to superficial water bodies [18-21]. Groundwater recharge is constrained during winter by freezing temperatures that reduce the available liquid water and during the growing season by intensive evapotranspiration rates $[4,19,22]$. Overall, hydrological systems are highly responsive to changes in the water cycle (e.g., spatio-temporal distribution of precipitation, rainfall intensity, snow accumulation, timing of snowmelt), thus propagating climate changes to the regional hydrology [23]. The impact of climate change in cold and humid regions characterized by an important rise of temperature in the future (especially during the winter season) and by uncertain future precipitation conditions [5,24-26], has been widely studied [2,4,27-33]. The decrease in snow water storage is recognized as a leading cause of low summer stream flows [29,34-36]. As winter temperatures increase, snow cover decreases and winter GWR events become more frequent and are associated with increased winter flow rates in rivers, as evapotranspiration remains very low $[4,22,30,37]$. Spring peaks of flow rates or GWR become subdued as snowdominated hydraulic regimes transition to rain-dominated regimes [4,11,15,29,33,38-41]. Although not yet well understood, these changes can be important for all groundwater users (humans, industries, ecosystems) and thus need to be studied and forecasted to support future water use policies.

Most climate change impact studies identify ranges of changes in hydrologic variables associated with the climate forcing of the climate scenarios used for simulation $[13,27,30,39,41,42]$. Reineke et al. [17] observed statistically significant changes in global-scale GWR for different warming levels $\left(+1\right.$ to $\left.+3^{\circ} \mathrm{C}\right)$. Similarly, Döll et al. [7] presented a global analysis of additional hydrologic hazard occurrence resulting from +1.5 and $+2{ }^{\circ} \mathrm{C}$ warming using hydrological indicators, including GWR. However, a range of changes can be insufficient to properly adapt infrastructures and policies to future conditions, as climate change signals usually overlap between climate models and RCPs. To overcome this, Crosbie et al. [13] provided data for water management scenarios using a scale of probability that simulated how future GWR would change from the simulated historical GWR at the Australian scale. Kløve et al. [9] suggested the use of indicators to communicate climate simulation results and representative parameters for use in water resource planning. These indicators of future conditions can be derived from winter low flows [27], GWR volumes [43], or water table depths [44], and can be expressed, for example, as functions of Quaternary deposits [27]. Meanwhile, identification of the evolution of precipitation and temperature changes that would lead to noticeable and statistically significant changes in GWR over time has not yet been undertaken. This assessment of the sensitivity of GWR to changes in climate variables, without a specific distinction between different climate forcing scenarios, would facilitate inter-study comparisons and provide simple and accessible indicators of future conditions for water managers [11].

This work aims to provide new insights into these questions. The objectives are (1) to simulate the effect of climate change on potential GWR in cold and humid climates and post-glacial geological environments and (2) to identify controlling processes and thresholds of GWR changes. As a regional-scale case study, this work focuses on future GWR conditions for the southern region of the Province of Quebec, Canada $\left(36,000 \mathrm{~km}^{2}\right)$, where the hydrology is dominated by long and cold winters. A spatially distributed water budget GWR model calibrated over the 1961-2017 period [22] was used with a set of 12 climate scenarios downscaled from global climate models (GCMs) using RCP4.5 (low emissions) and RCP8.5 (high emissions). The results were used to identify the controlling 
processes of GWR changes, as well as temperature and precipitation thresholds that lead to significant long-term changes emerging from future climate uncertainty.

\section{Data and Methods}

\subsection{Study Area}

A detailed description of the study area can be found in Dubois et al. [22] and is summarized hereafter. The study area is located in the province of Quebec (humid continental climate), between the St. Lawrence River and the Canada-USA border, and between the Quebec-Ontario border and Quebec City $\left(35,800 \mathrm{~km}^{2}\right)$ (Figure 1). It is comprised of the watersheds of eight main tributaries of the St. Lawrence River (numbered W1 to W8 from west to east) (Table 1). Watersheds W1, W2, and W4 have $42 \%, 83 \%$, and $15 \%$ of their total areas, respectively, located in the USA. The topography is flat, with low-elevation areas close to the St. Lawrence River and higher elevations in the Appalachian Mountains. The land cover includes agriculture (42\%), forest (45\%), wetlands $(6 \%)$, urban uses (5\%), and surface water $(2 \%)$. The annual average temperature varies between 6.5 (W1, west) and $3.9^{\circ} \mathrm{C}$ (W8, east), with the west-east cooling gradient also being notable during the cold months (December to March, $\mathrm{T}<0{ }^{\circ} \mathrm{C}$ ). The annual precipitation ranges between 952 (W1) and $1123 \mathrm{~mm} / \mathrm{yr}$ (W4), corresponding to an average of 231 (W3) to $142 \mathrm{~mm}$ (W7) of vertical inflow (VI; available liquid water = sum of rainfall and snowmelt) during the cold months.

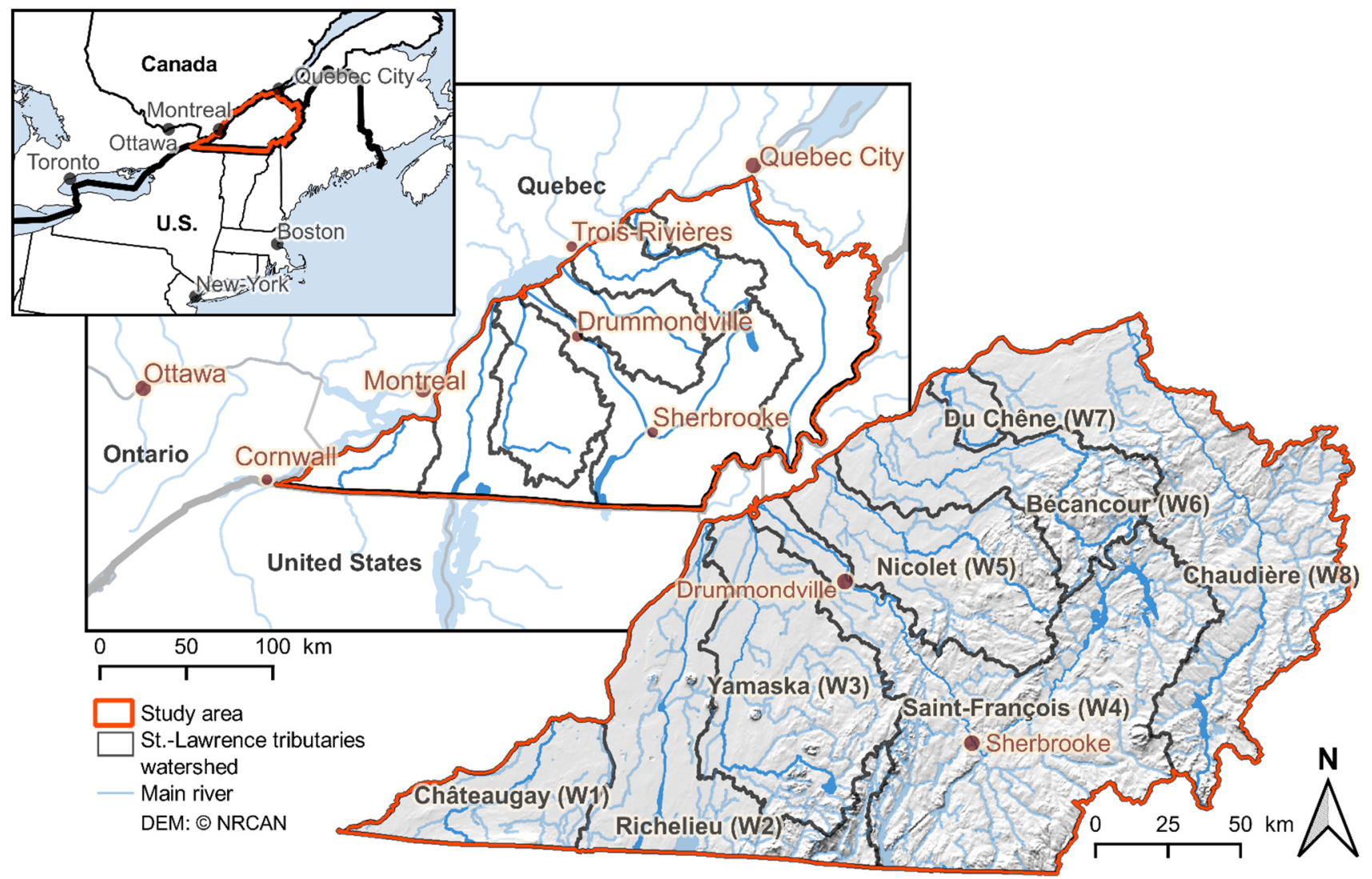

Figure 1. Location of the study area and the watersheds within. 
Table 1. Watershed characteristics, climate, and potential groundwater recharge (GWR) for the 1961-2017 period (from 22).

\begin{tabular}{|c|c|c|c|c|c|c|c|c|c|c|c|}
\hline & \multirow{2}{*}{$\begin{array}{c}\text { Area } \\
\left(\mathrm{km}^{2}\right)\end{array}$} & \multirow{2}{*}{$\begin{array}{l}\text { Median } \\
\text { Elevation } \\
\text { (m asl) }\end{array}$} & \multicolumn{2}{|c|}{ Annual } & \multicolumn{2}{|c|}{ Cold Months } & \multicolumn{5}{|c|}{ Pot. GWR } \\
\hline & & & $\begin{array}{c}\mathrm{T} \\
\left({ }^{\circ} \mathrm{C}\right)\end{array}$ & $P(\mathbf{m m})$ & $\begin{array}{c}\mathrm{T} \\
\left({ }^{\circ} \mathrm{C}\right)\end{array}$ & $\begin{array}{c}\mathrm{VI} \\
(\mathrm{mm})\end{array}$ & $\mathrm{mm} / \mathrm{yr}$ & Win. & Spr. & Sum. & Fall \\
\hline $\begin{array}{c}\text { W1. } \\
\text { Châteaugay * }\end{array}$ & 2219 & 51 & 6.5 & 952 & -6.4 & 211 & 109 & $38 \%$ & $46 \%$ & $3 \%$ & $14 \%$ \\
\hline W2. Richelieu * & 4414 & 40 & 6.3 & 1039 & -6.7 & 223 & 119 & $36 \%$ & $45 \%$ & $4 \%$ & $15 \%$ \\
\hline W3. Yamaska & 4792 & 80 & 5.9 & 1080 & -7.1 & 231 & 139 & $35 \%$ & $44 \%$ & $4 \%$ & $17 \%$ \\
\hline $\begin{array}{c}\text { W4. } \\
\text { Saint-François * }\end{array}$ & 9068 & 312 & 4.8 & 1123 & -7.8 & 214 & 147 & $31 \%$ & $42 \%$ & $8 \%$ & $19 \%$ \\
\hline W5. Nicolet & 3591 & 150 & 5.1 & 1076 & -8.0 & 196 & 144 & $32 \%$ & $43 \%$ & $6 \%$ & $19 \%$ \\
\hline W6. Bécancour & 3380 & 140 & 4.5 & 1103 & -8.7 & 164 & 151 & $28 \%$ & $44 \%$ & $7 \%$ & $21 \%$ \\
\hline W7. Du Chêne & 461 & 90 & 4.5 & 1092 & -8.9 & 142 & 154 & $26 \%$ & $46 \%$ & $8 \%$ & $20 \%$ \\
\hline W8. Chaudière & 7879 & 340 & 3.9 & 1092 & -8.9 & 151 & 145 & $27 \%$ & $42 \%$ & $10 \%$ & $21 \%$ \\
\hline
\end{tabular}

* Part of the watershed is located in the USA — the presented values are only for the Quebec part. Cold months = DJFM; Win. = DJF; Spr. = MAM; Sum. = JJA; Fall = SON; VI = vertical inflow (available liquid water, the sum of rainfall and snowmelt).

The study area includes two main geological units, the sedimentary basin of the St. Lawrence Platform and the metasedimentary Appalachian Mountains. The bedrock is unevenly covered with unconsolidated Quaternary sediments from the last glaciationdeglaciation cycle and is mainly composed of thin and coarse superficial materials deposited on the bedrock in the uphill areas, thick and mixed-grain size deposits in the valleys, and clay covering sandy materials close to the St. Lawrence River. Regional fractured bedrock aquifers flow from the Appalachians to the St. Lawrence River (south/southeast to north/northwest). The aquifers are moderately productive and are in unconfined conditions upstream and semi-confined to confined conditions in the valleys and in the St. Lawrence Lowlands [21]. Dubois et al. [22] estimated the average 1961-2017 regional potential GWR to be $139 \mathrm{~mm} / \mathrm{yr}$. They identified preferential recharge zones in the Appalachians, in forested areas, and over coarse deposits and outcropping bedrock. The potential GWR increases from west to east (Table 1). Warmer temperatures in the western watersheds (W1 to W3) are responsible for higher winter GWR rates (more VI) and lower summer and fall GWR rates (more actual evapotranspiration, AET) than in the eastern watersheds. The peak of the spring GWR, which is linked to snowmelt in April, dominates GWR in all the watersheds and corresponds to $44 \%$ of the annual GWR rates.

\subsection{Simulating Groundwater Recharge with Hydrobudget}

The HydroBudget model (HB) is a water budget GWR model developed to compute spatially distributed potential GWR on grid cells of regional-scale watersheds over long periods of time $[45,46]$. Using the spatially distributed daily temperature, daily total precipitation, and runoff curve number ( $\mathrm{RCN}$ - a combination of pedology, land cover, and slopes), HB is driven by eight parameters that require calibration (Table 2) and aggregates the output at a monthly time-step (although daily input data are required). For each daily time-step, HB computes the snow accumulation and melt (two parameters, $T_{M}$ and $C_{M}$ ), tests if the soil is frozen (two parameters, $T T_{F}$ and $F_{T}$ ), and partitions the superficial runoff (based on the RCN and with two parameters, $t_{A P I}$ and $f_{\text {runoff }}$ ) from the water that infiltrates into a conceptual soil reservoir (one parameter, $s w_{m}$ ). The AET corresponds to the minimum between the potential evapotranspiration calculated using the formula of Oudin et al. [47] and the available water in the soil reservoir. Part of the residual soil reservoir water is mobilized as potential GWR (one parameter, $f_{\text {inf }}$ ). Since HB does not simulate percolation out of the unsaturated zone, the potential GWR represents a maximum of GWR that could reach the saturated zone. For simplification, the simulated potential GWR will be hereon referred to as GWR. 
Table 2. Description of the HydroBudget parameters and calibrated values from Dubois et al. [22].

\begin{tabular}{|c|c|c|c|}
\hline & \multicolumn{2}{|c|}{ Parameter } & $\begin{array}{l}\text { Regionally Calibrated Value } \\
\text { from Dubois et al. [22] }\end{array}$ \\
\hline \multirow{2}{*}{ Snowmelt model } & Melting temperature- $-T_{M}\left({ }^{\circ} \mathrm{C}\right)$ & $\begin{array}{l}\text { Air temperature threshold for } \\
\text { snowmelt }\end{array}$ & 1.4 \\
\hline & $\begin{array}{l}\text { Melting coefficient }-C_{M} \\
\left(\mathrm{~mm} /{ }^{\circ} \mathrm{C} / \mathrm{d}\right)\end{array}$ & Melting rate of the snowpack & 4.9 \\
\hline \multirow{2}{*}{ Freezing soil conditions } & $\begin{array}{l}\text { Threshold temperature for soil } \\
\text { frost }-T T_{F}\left({ }^{\circ} \mathrm{C}\right)\end{array}$ & $\begin{array}{c}\text { Air temperature threshold for } \\
\text { soil frost }\end{array}$ & -15.9 \\
\hline & Freezing time $-F_{T}(\mathrm{~d})$ & $\begin{array}{l}\text { Duration of air temperature } \\
\text { threshold to freeze the soil }\end{array}$ & 16.4 \\
\hline \multirow[b]{2}{*}{ Runoff } & $\begin{array}{l}\text { Antecedent precipitation index } \\
\text { time }-t_{A P I}(\mathrm{~d})\end{array}$ & $\begin{array}{l}\text { Time constant to consider the } \\
\text { soil in dry or wet conditions } \\
\text { based on previous } \\
\text { precipitation event }\end{array}$ & 3.9 \\
\hline & Runoff factor- $-f_{\text {runoff }}(-)$ & $\begin{array}{l}\text { Correction factor for runoff } \\
\text { computed with the } \mathrm{RCN} \\
\text { method for the partitioning } \\
\text { between runoff and } \\
\text { infiltration into the soil } \\
\text { reservoir }\end{array}$ & 0.60 \\
\hline \multirow[t]{2}{*}{ Lumped soil reservoir } & $\begin{array}{l}\text { Maximum soil water } \\
\text { content-sw }-s w_{m}(\mathrm{~mm})\end{array}$ & $\begin{array}{l}\text { Soil reservoir storage capacity, } \\
\text { maximum height of water } \\
\text { stored in a } 1 \mathrm{~m} \text { soil profile }\end{array}$ & 385 \\
\hline & Infiltration factor- $f_{\text {inf }}(-)$ & $\begin{array}{l}\text { Fraction of soil water that } \\
\text { produces deep percolation at } \\
\text { each daily time step }\end{array}$ & 0.06 \\
\hline
\end{tabular}

Assuming that surface watersheds match hydrogeological watersheds and that rivers drain unconfined aquifers, Dubois et al. [22] calibrated HB by comparing the sum of the simulated superficial runoff and simulated GWR to the measured river flow and the simulated GWR to baseflow estimates (regressive filter on river flow time series). A multiobjective automatic calibration procedure was used with time series of river flow rates from 51 gauging stations over the 1961-2017 period and showed that the simulated variables had a small uncertainty $(\leq 10 \mathrm{~mm} / \mathrm{yr})$. Therefore, this regionally calibrated model was considered suitable to be used to simulate future GWR over the study area.

\subsection{Climate Scenarios}

A subset of 12 climate scenarios was derived from an ensemble of 54 climate simulations provided by 29 global climate models (GCMs) from the Coupled Model Intercomparison Project-Phase 5 (CMIP5) driven by RCP4.5 and RCP8.5 future greenhouse gas concentrations. The 12-member ensemble (Table 3) was created using the k-means clustering method proposed by Casajus et al. [48]. The climate scenario clustering process was constrained by ten criteria: the change in annual mean temperature and precipitation between the 1981-2010 period and the 2041-2070 period (two variables) and the changes in seasonal mean temperature and precipitation between the same periods (eight variables). Nine out of the 12 clusters comprised climate scenarios based on both RCPs. The algorithm selects the climate scenario closest to the cluster centroid as the candidate (not considering their RCP), as it best represents the average condition of future precipitation and temperature of the cluster. However, CanESM2 (CE2) was hand-picked from its respective cluster to include the Canadian GCM. The subset captures approximately $85 \%$ of the initial variance of the ensemble of 54 climate simulations. Casajus et al. [48] showed that this method 
retains a good representativity of the uncertainty linked to the climate scenarios between an ensemble of 27 climate scenarios and its subset of six.

Table 3. Selected climate scenarios.

\begin{tabular}{|c|c|c|c|}
\hline Name. & Model Source & Code & RCP \\
\hline ACCESS1-0_rcp45_r1i1p1 & $\begin{array}{c}\text { Commonwealth Scientific and Industrial Research Organization } \\
\text { (CSIRO), Australia and Bureau of Meteorology (BOM), } \\
\text { Australia }\end{array}$ & A10 & 4.5 \\
\hline ACCESS1-3_rcp85_r1i1p1 & $\begin{array}{c}\text { Commonwealth Scientific and Industrial Research Organization } \\
\text { (CSIRO), Australia and Bureau of Meteorology (BOM), } \\
\text { Australia }\end{array}$ & A13 & 8.5 \\
\hline bcc-csm1-1-m_rcp45_r1i1p1 & $\begin{array}{l}\text { Beijing Climate Center, China Meteorological Administration, } \\
\text { China }\end{array}$ & B1M & 4.5 \\
\hline BNU-ESM_rcp85_r1i1p1 & $\begin{array}{c}\text { College of Global Change and Earth System Science, Beijing } \\
\text { Normal University (BNU), China }\end{array}$ & $\mathrm{BNU}$ & 8.5 \\
\hline CanESM2_rcp45_r1i1p1 & $\begin{array}{l}\text { Canadian Center for Climate Modelling and Analysis (CCCma), } \\
\text { Canada }\end{array}$ & CE2 & 4.5 \\
\hline CMCC-CMS_rcp45_r1i1p1 & $\begin{array}{l}\text { Centro Euro-Mediterraneo sui Cambiamenti Climatici Climate } \\
\text { Model, Italy }\end{array}$ & CMS & 4.5 \\
\hline GFDL-CM3_rcp45_r1i1p1 & Geophysical Fluid Dynamics Laboratory (GFDL), USA & GF3 & 4.5 \\
\hline GISS-E2-R_rcp45_r6i1p3 & $\begin{array}{l}\text { National Aeronautics and Space Administration } \\
\text { (NASA)/Goddard Institute for Space Studies (GISS), USA }\end{array}$ & GIR & 4.5 \\
\hline inmcm4_rcp45_r1i1p1 & Institute for Numerical Mathematics (INM), Russia & INM & 4.5 \\
\hline MIROC-ESM_rcp45_r1i1p1 & $\begin{array}{l}\text { Japan Agency for Marine-Earth Science and Technology, } \\
\text { Atmosphere and Ocean Research Institute (The University of } \\
\text { Tokyo), National Institute for Environmental Studies, Japan }\end{array}$ & MIC & 8.5 \\
\hline $\begin{array}{l}\text { MIROC-ESM- } \\
\text { CHEM_rcp85_r1i1p1 }\end{array}$ & $\begin{array}{l}\text { Japan Agency for Marine-Earth Science and Technology, } \\
\text { Atmosphere and Ocean Research Institute (The University of } \\
\text { Tokyo), National Institute for Environmental Studies, Japan }\end{array}$ & MIE & 4.5 \\
\hline MRI-ESM1_rcp85_r1i1p1 & Meteorological Research Institute, Japan & MRE & 8.5 \\
\hline
\end{tabular}

The 12 selected simulations were bias-corrected to a 1981-2010 reference dataset (Natural Resources Canada gridded observation database) [49,50] and downscaled to the reference $10 \mathrm{~km} \times 10 \mathrm{~km}$ resolution using the quantile mapping approach by Mpelasoka and Chiew [51]. With these scenarios, changes in mean annual temperature and annual precipitation between the 1981-2010 and 2041-2070 periods ( $\Delta \mathrm{T}$ and $\Delta \mathrm{P}$, respectively) covered most of the combinations of $\Delta \mathrm{T}$ and $\Delta \mathrm{P}$ found in the ensemble of 54 climate scenarios (Figure 2a). $\Delta \mathrm{T}$ ranged between +0.9 (INM, RCP4.5) and $+5.0{ }^{\circ} \mathrm{C}(\mathrm{MIC}, \mathrm{RCP} 8.5)$ and $\Delta \mathrm{P}$ ranged between $+5(\mathrm{~B} 1 \mathrm{M}, \mathrm{RCP} 4.5)$ and $+200 \mathrm{~mm}(\mathrm{~A} 13, \mathrm{RCP} 8.5)$. The change in mean temperature during the cold months (December to November; $\Delta \mathrm{T}_{\mathrm{CM}}$ ) was between +1.1 (INM, RCP4.5) and $+6.0^{\circ} \mathrm{C}$ (MIC, RCP8.5) (Figure 2b). The change in precipitation during the cold months $\left(\Delta \mathrm{P}_{\mathrm{CM}}\right)$ was between $+17(\mathrm{MIE}, \mathrm{RCP} 4.5)$ and $+100 \mathrm{~mm}(\mathrm{GF3}, \mathrm{RCP} 4.5)$. The warming temperature during the cold months led to $\Delta \mathrm{VI}_{\mathrm{CM}}$ between +33 (INM, RCP4.5) and +215 mm (MIC, RCP8.5) (Figure 2c).

\subsection{Period Comparisons and Significant Changes}

The simulation period was divided into four 30-year periods: 1981-2010, the reference period, also used as the baseline for the bias correction of the climate scenarios, and three future periods, 2011-2040, 2041-2070, and 2071-2100. The same periods were used to present the results of the 96 GWR scenarios (12 scenarios for 8 watersheds). Each 30-year period was compared to the previous one and to the 1981-2010 reference period to observe the simulated range in future GWR and to identify future GWR changes. 

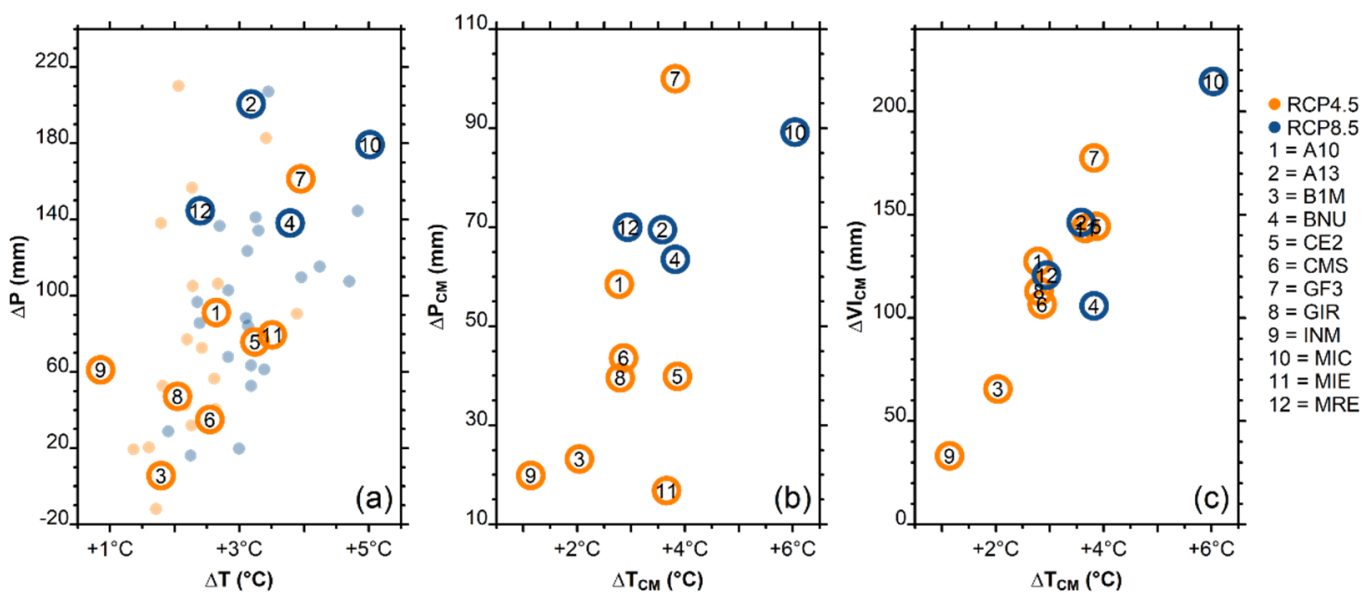

Figure 2. Changes $(\Delta)$ between the reference period (1981-2010) and the 2041-2070 horizon for the 12 selected climate scenarios in the study area in (a) annual precipitation $(\Delta \mathrm{P})$ as a function of mean annual temperature $(\Delta \mathrm{T})$ within the ensemble of 54 climate scenarios (27 RCP4.5 and 27 RCP8.5), (b) cold month (December to March) precipitation $\left(\Delta \mathrm{P}_{\mathrm{CM}}\right)$ as a function of mean cold month temperature $\left(\Delta \mathrm{T}_{\mathrm{CM}}\right)$, and (c) vertical inflow during the cold months (sum of liquid precipitation and snowmelt; $\left.\Delta \mathrm{VI}_{\mathrm{CM}}\right)$ as a function of mean cold month temperature $\left(\Delta \mathrm{T}_{\mathrm{CM}}\right)$.

Changes in precipitation, temperature, and GWR were determined to be statistically significant based on the Tukey test $(p<0.05)$, comparing the results of each 30 -year period and the previous one or between the future periods and the reference period. The sample size in each group varied between 30 values, when monthly or annual variables for each watershed and each scenario were compared, and 360 values for the monthly or annual variables for each watershed (or grid cells) when all the scenarios were compared.

\section{Results}

\subsection{Climate Changes for the 1981-2100 Period}

The average evolution of annual precipitation and mean temperature from the 12 scenarios for each watershed and for each 30-year period shows a constant increase throughout the century (Figure 3). All increases between each 30-year period and the previous one (30 years and 12 scenarios corresponding to 360 values for each period) were statistically significant. The range of precipitation and temperature changes, represented by the difference between the minimum and the maximum of the 12 scenarios for each year, increased remarkably from the 1981-2010 period to the 2071-2100 period (Figure 3).

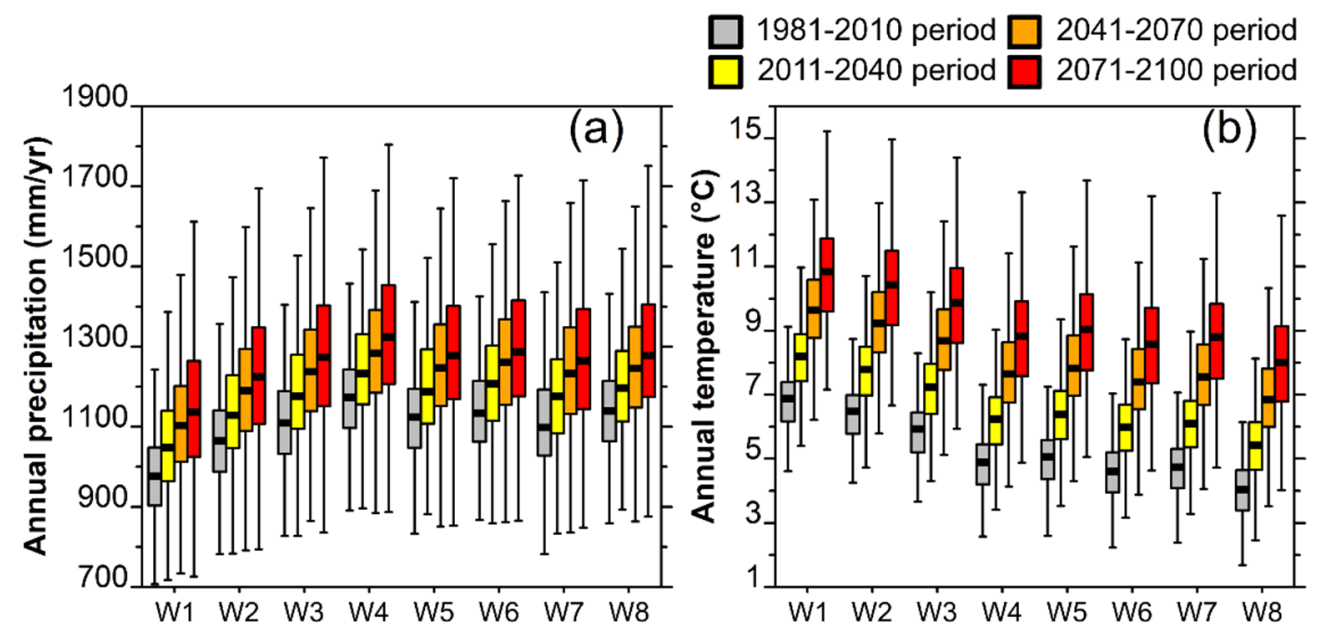

Figure 3. Thirty-year period change of mean annual precipitation (a) and annual temperature (b) of the 12 climate scenarios for the eight watersheds (W1 to W8). 


\subsection{Groundwater Recharge for the 1981-2100 Period}

The previously calibrated HB model [22] was used to simulate future GWR under the 12 climate scenarios for the entire 1951-2100 period with a monthly time-step and a $500 \mathrm{~m}$ $\times 500 \mathrm{~m}$ spatial resolution. Although simulations were performed for the 1951-2100 period, GWR changes were only compared between three future periods (2011-2040, 2041-2070, 2071-2100) and the previous period (including the 1981-2010 reference period). The 30-year moving averages for all GWR scenarios ranged between 126 (W1) and $183 \mathrm{~mm} / \mathrm{yr}$ (W6) (Figure 4). The ensemble mean GWR increased between +5 (W8) and $+17 \mathrm{~mm} / \mathrm{yr}(\mathrm{W} 1)$ from the 1981-2010 period to the 2071-2100 period, with maximum increases of $+5 \mathrm{~mm} / \mathrm{yr}$ between two consecutive 30-year periods (Table 4). Six climate scenarios produced GWR rates higher than the ensemble mean (A13, BNU, CMS, GIR, MIC, MRE, RCP8.5, and RCP4.5). The other six climate scenarios (A10, B1M, CE2, GF3, INM, MIE, and RCP4.5) produced GWR rates lower than the ensemble mean. Climate scenarios based on RCP8.5 produced higher GWR rates (although not always the highest).

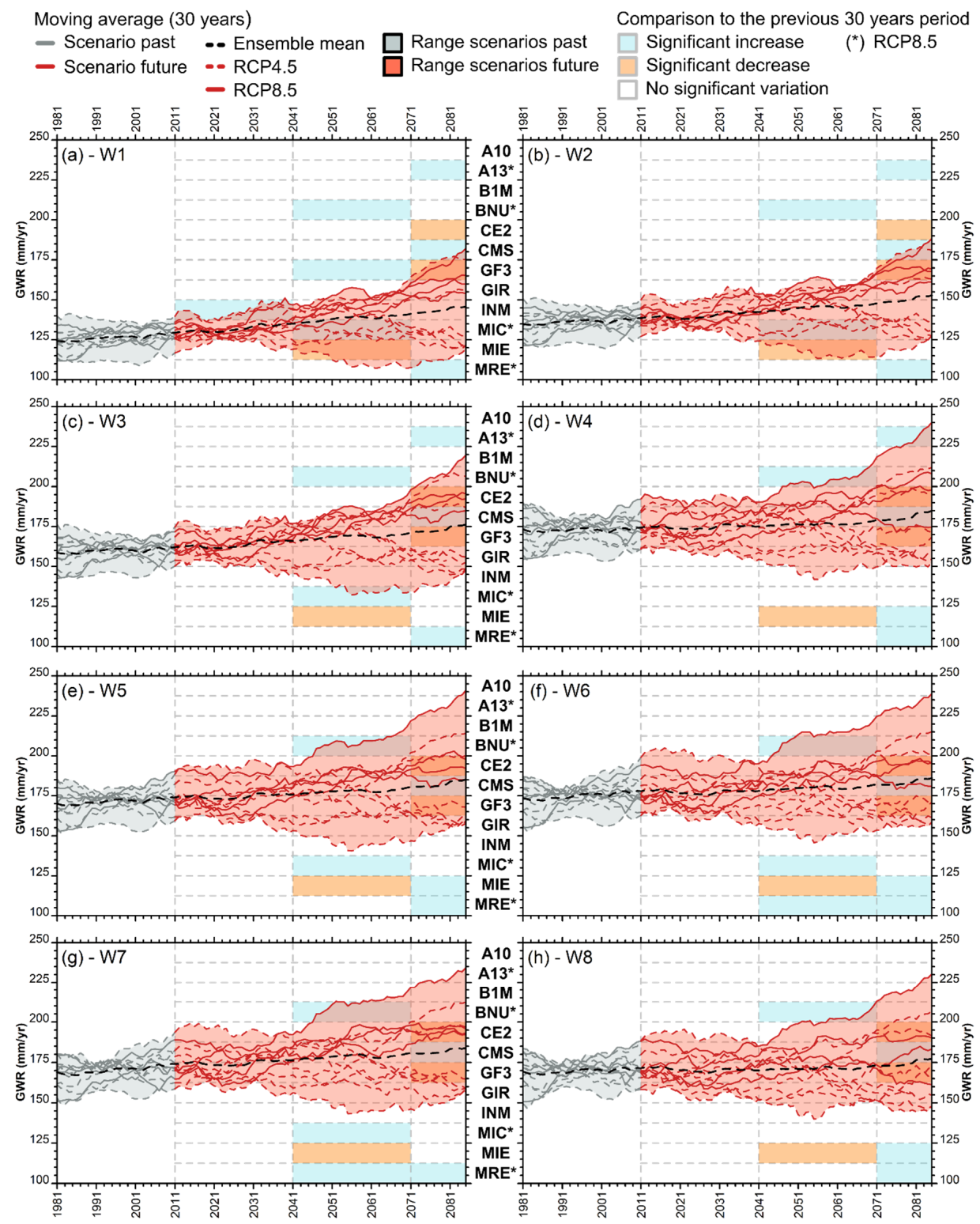

Figure 4. Thirty-year moving average of groundwater recharge (GWR) simulated with the 12 climate scenarios and significant changes (Tukey test, $p<0.05$ ) between subsequent 30-year periods (20112040, 2041-2070, and 2071-2100) for (a) W1 to (h) W8. 
Table 4. Thirty-year evolution of mean groundwater recharge $(\mathrm{mm} / \mathrm{yr})$, range of the ensemble changes (in brackets), and evolution of the cold month groundwater recharge from December to March $\left(\mathrm{T}<0{ }^{\circ} \mathrm{C}\right)$ and that from May to November $\left(\mathrm{T}>0{ }^{\circ} \mathrm{C}\right)(\mathrm{mm})$ of the 12 climate scenarios for the eight watersheds (W1 to W8).

\begin{tabular}{|c|c|c|c|c|c|c|c|c|c|c|c|c|c|c|c|c|}
\hline & \multicolumn{2}{|c|}{ W1 } & \multicolumn{2}{|c|}{ W2 } & \multicolumn{2}{|c|}{ W3 } & \multicolumn{2}{|c|}{ W4 } & \multicolumn{2}{|c|}{ W5 } & \multicolumn{2}{|c|}{ W6 } & \multicolumn{2}{|c|}{ W7 } & \multicolumn{2}{|c|}{ W8 } \\
\hline & $\mathrm{CM}$ & WM & $\mathrm{CM}$ & WM & $\mathrm{CM}$ & WM & $\mathrm{CM}$ & WM & $\mathrm{CM}$ & WM & $\mathrm{CM}$ & WM & CM & WM & $\mathrm{CM}$ & WM \\
\hline 1981- & \multicolumn{2}{|c|}{$126(26)$} & \multicolumn{2}{|c|}{$136(24)$} & \multicolumn{2}{|c|}{$160(26)$} & \multicolumn{2}{|c|}{$173(28)$} & \multicolumn{2}{|c|}{$171(26)$} & \multicolumn{2}{|c|}{$175(28)$} & \multicolumn{2}{|c|}{$170(28)$} & \multicolumn{2}{|c|}{$170(24)$} \\
\hline 2010 & 74 & 31 & 74 & 39 & 80 & 53 & 75 & 71 & 77 & 66 & 71 & 74 & 66 & 72 & 66 & 77 \\
\hline 2011- & \multicolumn{2}{|c|}{$132(22)$} & \multicolumn{2}{|c|}{$140(22)$} & \multicolumn{2}{|c|}{$164(26)$} & \multicolumn{2}{|c|}{$175(34)$} & \multicolumn{2}{|c|}{$175(34)$} & \multicolumn{2}{|c|}{$177(38)$} & \multicolumn{2}{|c|}{$175(36)$} & \multicolumn{2}{|c|}{$171(36)$} \\
\hline 2040 & 82 & 27 & 82 & 33 & 89 & 45 & 85 & 61 & 86 & 57 & 81 & 64 & 77 & 64 & 75 & 67 \\
\hline 2041- & \multicolumn{2}{|c|}{$138(42)$} & \multicolumn{2}{|c|}{$145(42)$} & \multicolumn{2}{|c|}{$168(48)$} & \multicolumn{2}{|c|}{$176(54)$} & \multicolumn{2}{|c|}{$178(60)$} & \multicolumn{2}{|c|}{$180(60)$} & \multicolumn{2}{|c|}{$178(60)$} & \multicolumn{2}{|c|}{$171(50)$} \\
\hline 2070 & 93 & 25 & 93 & 30 & 102 & 41 & 96 & 54 & 99 & 51 & 94 & 57 & 90 & 58 & 85 & 58 \\
\hline 2071- & \multicolumn{2}{|c|}{$143(60)$} & \multicolumn{2}{|c|}{$150(60)$} & \multicolumn{2}{|c|}{$173(68)$} & & 76) & & 78) & & 76) & & 76) & & 74) \\
\hline 2100 & 101 & 22 & 102 & 27 & 112 & 36 & 107 & 48 & 110 & 45 & 105 & 50 & 102 & 50 & 97 & 51 \\
\hline
\end{tabular}

$\mathrm{CM}=$ sum of groundwater recharge for the "cold months", from December to March $\left(\mathrm{T}<0^{\circ} \mathrm{C}\right)$; $\mathrm{WM}=\operatorname{sum}$ of groundwater recharge for the "warm months", from May to November $\left(\mathrm{T}>0{ }^{\circ} \mathrm{C}\right)$.

The range of changes in the GWR scenarios was smallest for the 1981-2010 period (2011-2040 for W1 and W2), with values between 22 (W1 and W2) and $28 \mathrm{~mm} / \mathrm{yr}$ (W4, W6, and W7) (Table 4). It increased markedly in the 2041-2070 period, with values between 42 (W1 and W2) and $60 \mathrm{~mm} / \mathrm{yr}$ (W5, W6, and W7). It increased even more during the 2071-2100 period, reaching values of between 60 (W1 and W2) and $78 \mathrm{~mm} / \mathrm{yr}$ (W5). This larger range of the results was due to the increasing range in precipitation changes between the scenarios in the second half of the 21st century (Figure 3).

The climate changes associated with each significant $\Delta$ GWR between 30 -year periods (not using the 30-year moving average) are reported in Table 5. Although there was a general increase in temperature between 1981 and 2100, a relatively small number of significant inter-period $\triangle G W R$ were observed (Figure 4). This could be due to the combined effect of increased evapotranspiration triggered by higher temperature and increased precipitation. As such, the direction of the $\Delta \mathrm{GWR}$ change was not directly linked to the change in precipitation $(\Delta \mathrm{P})$. For example, $\Delta \mathrm{GWR}>0$ (increase) was associated with $\Delta \mathrm{P}<0$ (CMS for the 2071-2100 period, compared to 2041-2070 for W3 and W8), while $\Delta \mathrm{GWR}<0$ (decrease) was simulated with $\Delta \mathrm{P}>0$ (CE2 and GF3 for the 2071-2100 period compared to 2041-2070 for W3 and W8; MIE for the 2041-2070 period compared to 2011-2040 for W3, W6, and W8). An average temperature change $(\Delta \mathrm{T})$ of $+1.2^{\circ} \mathrm{C}$ was associated with $\Delta \mathrm{GWR}<0$ (between +0.7 and $+2.3{ }^{\circ} \mathrm{C}$ ), while an average $\Delta \mathrm{T}$ of $+1.8^{\circ} \mathrm{C}$ was associated with $\Delta \mathrm{GWR}>0$ (between +0.2 and $+2.8^{\circ} \mathrm{C}$ ). The four climate scenarios based on RCP8.5, representing mainly very humid future conditions, produced statistically significant $\Delta \mathrm{GWR}>0$ for one of the last two future periods, except for A13 in the eastern watersheds (W5 to W8; Figure 4e-h). The climate scenarios based on RCP4.5, representing both moderately and very humid future conditions, produced both $\Delta \mathrm{GWR}<0$ and $\Delta \mathrm{GWR}>0$ for different periods. In addition, the changes between the 1981-2010 and the 2011-2040 periods were not statistically significant (only one significant change in W1 for one scenario; Figure 4a).

Overall, the GWR simulations showed minor variation prior to 2041, and the main changes occurred during the last two future periods, 2041-2070 and 2071-2100. Therefore, only these two future periods will be considered in the rest of the analysis. 
Table 5. Mean annual precipitation $(\Delta \mathrm{P})$ and temperature $(\Delta \mathrm{T})$ changes between 30 -year periods associated with significant changes in groundwater recharge $(\Delta \mathrm{GWR})$ for the 12 climate scenarios and eight watersheds (W1 to W8) (cell color represents the direction of the $\Delta G W R$ : orange for decrease and blue for increase, cells are empty when $\triangle G W R$ was not significant).

\begin{tabular}{|c|c|c|c|c|c|c|c|c|c|c|c|c|c|c|c|c|c|}
\hline \multirow{3}{*}{$\begin{array}{l}\text { Climate } \\
\text { Scenario }\end{array}$} & \multirow{3}{*}{ Period ** } & \multicolumn{16}{|c|}{ Precipitation $(\mathrm{mm})$ and Temperature $\left({ }^{\circ} \mathrm{C}\right)$ Changes Compared to Previous 30-Year Period } \\
\hline & & \multicolumn{2}{|c|}{ W1 } & \multicolumn{2}{|c|}{ W2 } & \multicolumn{2}{|c|}{ W3 } & \multicolumn{2}{|c|}{ W4 } & \multicolumn{2}{|c|}{ W5 } & \multicolumn{2}{|c|}{ W6 } & \multicolumn{2}{|c|}{ W7 } & \multicolumn{2}{|c|}{ W8 } \\
\hline & & $\Delta \mathbf{P}$ & $\Delta \mathrm{T}$ & $\Delta \mathbf{P}$ & $\Delta \mathrm{T}$ & $\Delta \mathbf{P}$ & $\Delta \mathrm{T}$ & $\Delta \mathbf{P}$ & $\Delta \mathrm{T}$ & $\Delta \mathbf{P}$ & $\Delta \mathrm{T}$ & $\Delta \mathbf{P}$ & $\Delta \mathrm{T}$ & $\Delta \mathbf{P}$ & $\Delta \mathrm{T}$ & $\Delta \mathbf{P}$ & $\Delta \mathrm{T}$ \\
\hline A13* & 3 & 198 & 1.9 & 200 & 1.9 & 113 & 1.8 & 191 & 1.9 & & & & & & & & \\
\hline $\mathrm{BNU}$ * & 2 & 119 & 2.6 & 121 & 2.6 & 39 & 1.1 & 121 & 2.6 & 116 & 2.6 & 118 & 2.6 & 119 & 2.6 & 40 & 1.1 \\
\hline CE2 & 3 & -45 & 0.7 & -47 & 0.7 & 34 & 1.6 & -47 & 0.7 & -36 & 0.7 & -30 & 0.7 & & & 13 & 1.6 \\
\hline CMS & 3 & 180 & 0.9 & 183 & 0.9 & -39 & 1.0 & 181 & 0.9 & 179 & 1.0 & 184 & 1.0 & 188 & 1.0 & -38 & 1.0 \\
\hline GF3 & 2 & 92 & 2.1 & & & & & & & & & & & & & & \\
\hline GF3 & 3 & -57 & 0.7 & -60 & 0.7 & 79 & 2.1 & -63 & 0.7 & -60 & 0.8 & -48 & 0.8 & -51 & 0.8 & 61 & 2.3 \\
\hline INM & 1 & 36 & 0.2 & & & & & & & & & & & & & & \\
\hline $\mathrm{MIC}^{*}$ & 2 & 176 & 2.8 & 182 & 2.8 & 68 & 2.2 & & & 158 & 2.8 & 145 & 2.7 & 176 & 2.8 & & \\
\hline MIE & 2 & -11 & 1.6 & -16 & 1.6 & 94 & 1.7 & -18 & 1.6 & -4 & 1.5 & 8 & 1.5 & -15 & 1.6 & 60 & 1.7 \\
\hline MIE & 3 & & & & & & & -6 & 1.2 & 16 & 1.2 & 35 & 1.2 & & & 25 & 1.4 \\
\hline MRE * & 2 & & & & & & & & & & & 117 & 1.5 & 120 & 1.5 & & \\
\hline MRE * & 3 & 135 & 1.9 & 144 & 1.9 & 88 & 1.5 & 146 & 1.9 & 127 & 1.9 & 100 & 1.9 & 88 & 1.9 & 104 & 1.5 \\
\hline
\end{tabular}

* Represents RCP8.5 (scenarios without an * represent RCP4.5). ${ }^{* *}$ Period 1 is 2011-2040, Period 2 is 2041-2070, and Period 3 is $2071-2100$

\subsection{Inter-Annual Changes in Groundwater Recharge}

The $\triangle$ GWR between the two future periods and the reference period for each climate scenario can be represented as a function of different variables (Figure 5). For each scenario, significant $\Delta \mathrm{GWR}<0$ was associated with $\Delta \mathrm{P}<+150 \mathrm{~mm}$ for all watersheds except $\mathrm{W} 1$ (Figure $5 \mathrm{a}, \mathrm{b}$ ). Inversely, significant $\Delta \mathrm{GWR}>0$ was obtained when $\Delta \mathrm{P}>+150 \mathrm{~mm}$. The few scenarios with $\Delta \mathrm{P}<0 \mathrm{~mm}$ always led to $\Delta \mathrm{GWR}<0$ (some significant, some not; Figure $5 \mathrm{~b}$ ). All the significant $\Delta \mathrm{GWR}<0$ were simulated for $+3{ }^{\circ} \mathrm{C}<\Delta \mathrm{T}<+5{ }^{\circ} \mathrm{C}$, while significant $\Delta \mathrm{GWR}>0$ were obtained for $+2{ }^{\circ} \mathrm{C}<\Delta \mathrm{T}<+8^{\circ} \mathrm{C}$ (Figure $5 \mathrm{a}, \mathrm{c}$ ). $\Delta \mathrm{GWR}$ seemed to plateau at approximately $+30 \mathrm{~mm}$ for both $\Delta \mathrm{T}>+4.5^{\circ} \mathrm{C}$ (Figure $5 \mathrm{~b}, \mathrm{c}, \mathrm{h}$, note triangle markers) and $\Delta \mathrm{T}_{\mathrm{CM}}>+6{ }^{\circ} \mathrm{C}$ (Figure $5 \mathrm{f}$, December to March). Using $\Delta \mathrm{T}_{\mathrm{CM}}$ and $\Delta \mathrm{P}_{\mathrm{CM}}$ showed that $\Delta \mathrm{GWR}<0$ occurred with $\Delta \mathrm{P}_{\mathrm{CM}}<+25 \mathrm{~mm}$ and $+3{ }^{\circ} \mathrm{C}<\Delta \mathrm{T}_{\mathrm{CM}}<+5{ }^{\circ} \mathrm{C}$, except for one scenario in W3 and W8 (Figure $5 \mathrm{~d}-\mathrm{f}$ ). All significant $\Delta \mathrm{GWR}$ were simulated with $\Delta \mathrm{T}_{\mathrm{CM}}>$ $+3{ }^{\circ} \mathrm{C}$ (Figure 5f). Significant $\Delta \mathrm{GWR}<0$ were systematically associated with change in cold month GWR $\left(\Delta G W R_{C M}\right)<+25 \mathrm{~mm}$ and inversely for $\Delta \mathrm{GWR}>0$ (Figure $5 \mathrm{~g}$ ). Significant $\triangle \mathrm{GWR}<0$ were simulated with scenarios of limited changes in annual simulated AET $(+50 \mathrm{~mm}<\Delta$ AET $<+95 \mathrm{~mm})$, while $\triangle \mathrm{AET}>+120 \mathrm{~mm}$ were associated with limited GWR increase (plateau around $+30 \mathrm{~mm}$ ) and a $\Delta \mathrm{T}>+4.5^{\circ} \mathrm{C}$ (Figure $5 \mathrm{~h}$ ). All significant annual $\Delta$ GWR were $<-15$ or $>+15 \mathrm{~mm}$ (Figure $5 \mathrm{~b}, \mathrm{c}, \mathrm{e}-\mathrm{h}$ ).

Of the 96 GWR simulations, 20 produced a statistically significant $\Delta$ GWR between the 1981-2010 and 2041-2070 periods, including 11 based on RCP8.5, and 39 between the 1981-2010 and 2071-2100 periods, including 21 based on RCP8.5 (Table 6). Although scenarios based on RCP8.5 did not always produce significant $\triangle \mathrm{GWR}$, they were more likely to produce significant $\triangle \mathrm{GWR}$ than those based on RCP4.5. The greater number of significant changes simulated for the 2071-2100 period in comparison to the 2041-2070 period confirmed that GWR was more affected with more pronounced climate changes, be it through greater emissions or longer progression. 

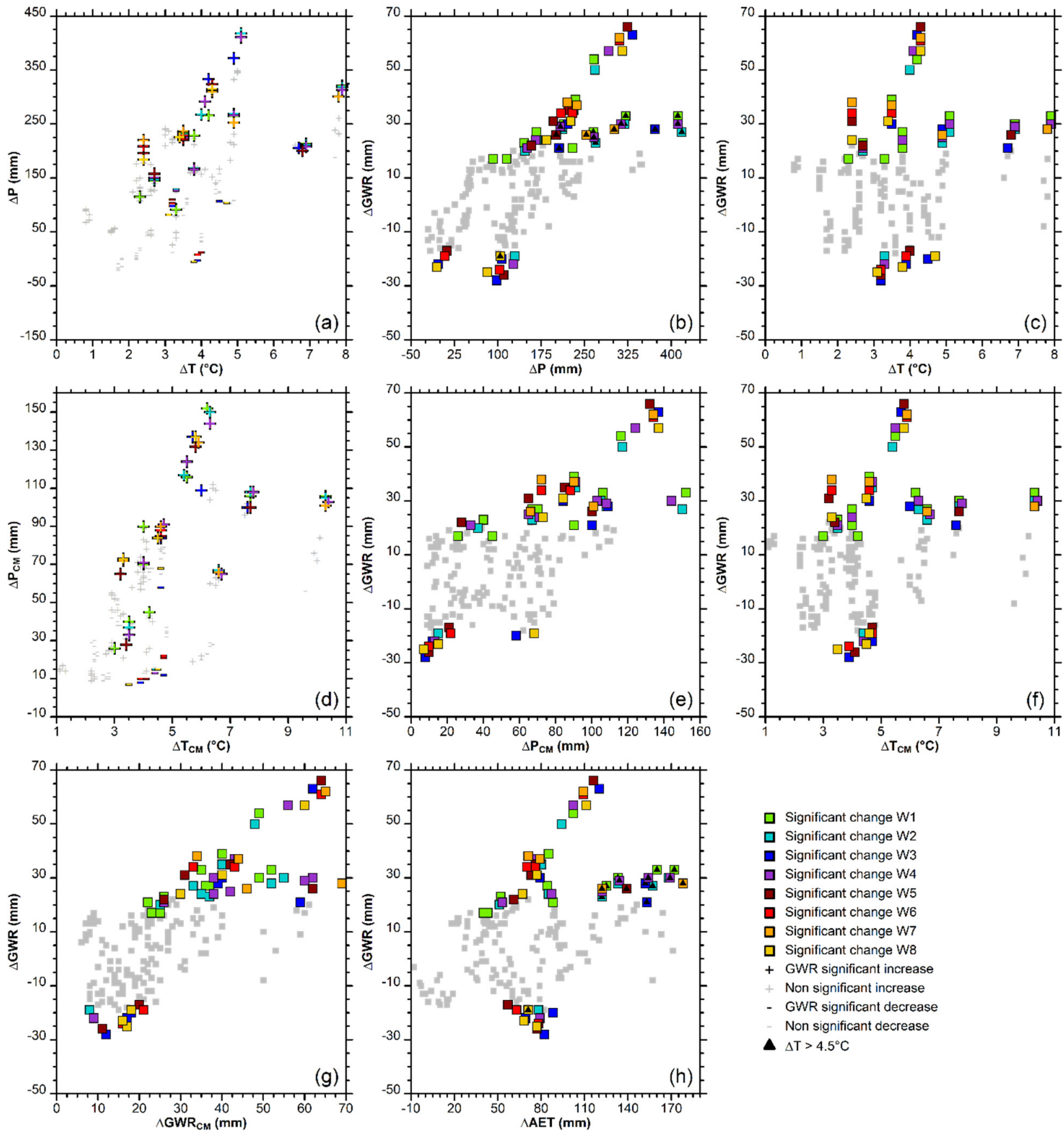

ㄴ Significant change $W 1$

口 Significant change W2

- Significant change $W_{3}$

Significant change $W 4$

- Significant change $W 5$

- Significant change W6

- Significant change W7

Significant change W8

+ GWR significant increase

Non significant increase

- GWR significant decrease

Non significant decrease

$\Delta \Delta \mathrm{T}>4.5^{\circ} \mathrm{C}$

Figure 5. Changes in annual groundwater recharge ( $\triangle \mathrm{GWR}$ ) between the reference period (1981-2010) and the 2041-2070 and 2071-2100 periods as a function of (a) changes in mean annual temperature $(\Delta \mathrm{T})$ and annual precipitation $(\Delta \mathrm{P}),(\mathbf{b})$ annual precipitation changes $(\Delta \mathrm{P}),(\mathbf{c})$ mean annual temperature changes $(\Delta \mathrm{T}),(\mathrm{d})$ mean cold month temperature changes $\left(\Delta \mathrm{T}_{\mathrm{CM}}\right)$ and cold month precipitation changes $\left(\Delta \mathrm{P}_{\mathrm{CM}}\right),(\mathbf{e})$ cold month precipitation changes $\left(\Delta \mathrm{P}_{\mathrm{CM}}\right),(\mathbf{f})$ mean cold month temperature changes $\left(\Delta \mathrm{T}_{\mathrm{CM}}\right),(\mathrm{g})$ cold month groundwater recharge changes $\left(\Delta \mathrm{GWR} \mathrm{R}_{\mathrm{CM}}\right)$, and $(\mathbf{h})$ annual actual evapotranspiration changes $(\triangle \mathrm{AET})$.

Table 6. Number of simulations with significant changes in groundwater recharge between the 1981-2010 reference period and the future periods for the eight watersheds (W1 to W8); the number of scenarios based on RCP8.5 producing significant changes is indicated in brackets.

\begin{tabular}{ccccccccc}
\hline & W1 & W2 & W3 & W4 & W5 & W6 & W7 & W8 \\
\hline $2041-2070$ & $5[2]$ & $3[2]$ & $1[0]$ & $3[2]$ & $2[1]$ & $2[1]$ & $2[2]$ & $2[1]$ \\
$2071-2100$ & $6[4]$ & $6[4]$ & $6[3]$ & $6[4]$ & $5[2]$ & $3[1]$ & $3[2]$ & $4[1]$ \\
\hline
\end{tabular}




\subsection{Spatial Changes in Groundwater Recharge over Time}

The changes in future GWR (future periods vs. the reference period) were analyzed spatially on a cell-by-cell basis with the ensemble of scenarios (Figures 6 and 7). For the months of January, February, and March, and to a lesser extent for the month of December, significant $\Delta G W R>0$ was simulated for all watersheds, between +1 and $>+5 \mathrm{~mm}$ for the 2041-2070 period, and mainly $>+5 \mathrm{~mm}$ for the 2071-2100 period, as well as between +1 and $+5 \mathrm{~mm}$ for December for the two periods. Although half of the changes were not significant in April for the two future periods, a clear pattern appeared during that month, with $-5 \mathrm{~mm}<\Delta \mathrm{GWR}<-1 \mathrm{~mm}$ in the western portion of the study area and $+1 \mathrm{~mm}$ $<\Delta \mathrm{GWR}<+5 \mathrm{~mm}$ in the eastern portion. In May and June, significant $\Delta \mathrm{GWR}<0$ was simulated, which was lower eastward and for the 2071-2100 period (locally $<-5 \mathrm{~mm}$ ). Generalized significant decreases of $-5 \mathrm{~mm}<\Delta \mathrm{GWR}<-1 \mathrm{~mm}$ were simulated for July, August, and September for the two future periods. The $\Delta$ GWR was mainly between -5 and $-1 \mathrm{~mm}$ from July to November for the two future periods. Non-significant $\Delta \mathrm{GWR}$ $<0$ was simulated in these months in the western and central portions of the study area. Significant $\Delta G W R<-5 \mathrm{~mm}$ was also simulated in the eastern portion for the two future periods in October and to a lesser extent in November.
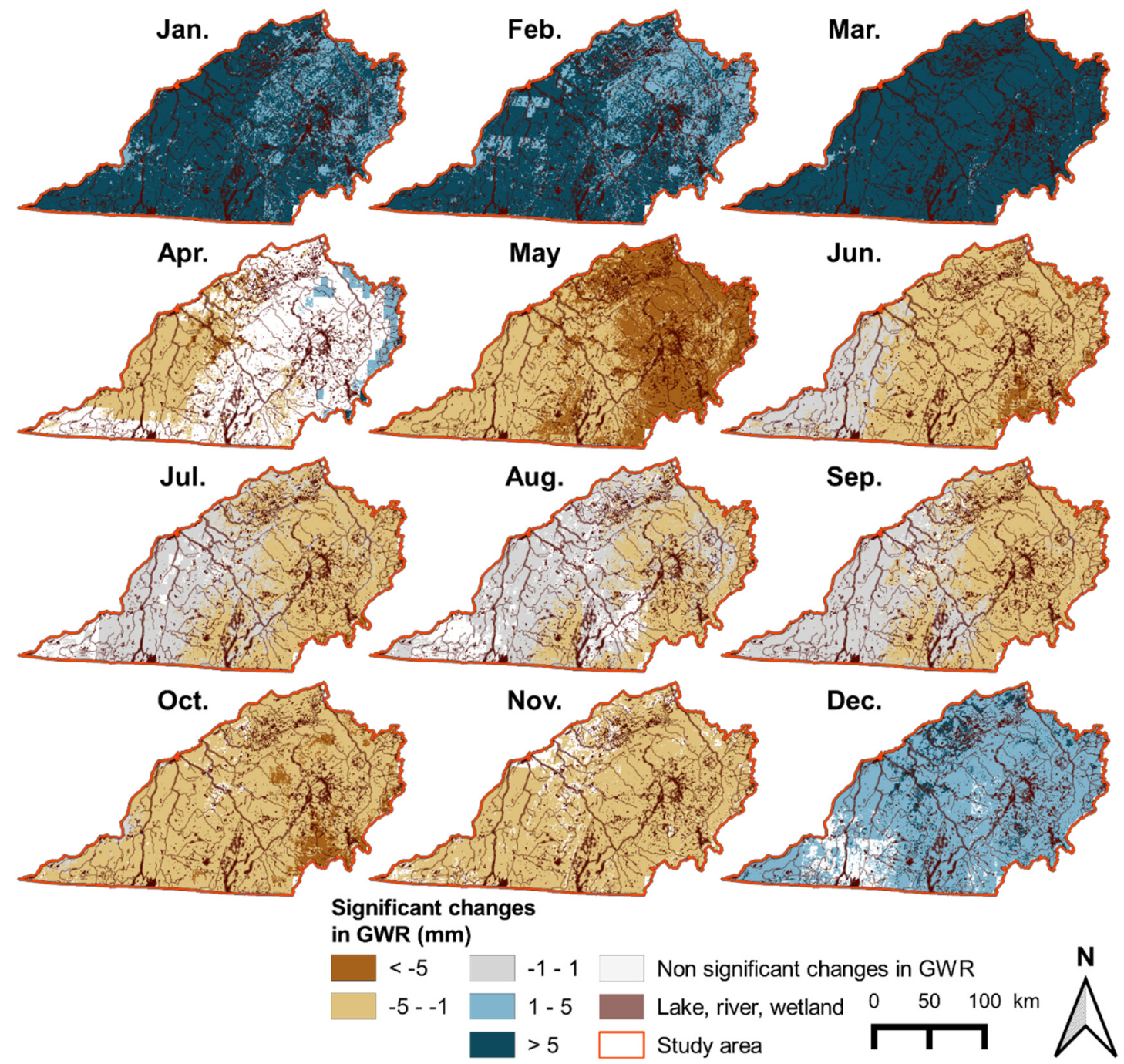

Figure 6. Spatial changes in average monthly groundwater recharge (GWR) between the reference period (1981-2010) and the 2041-2070 period for the 12 climate scenarios. 


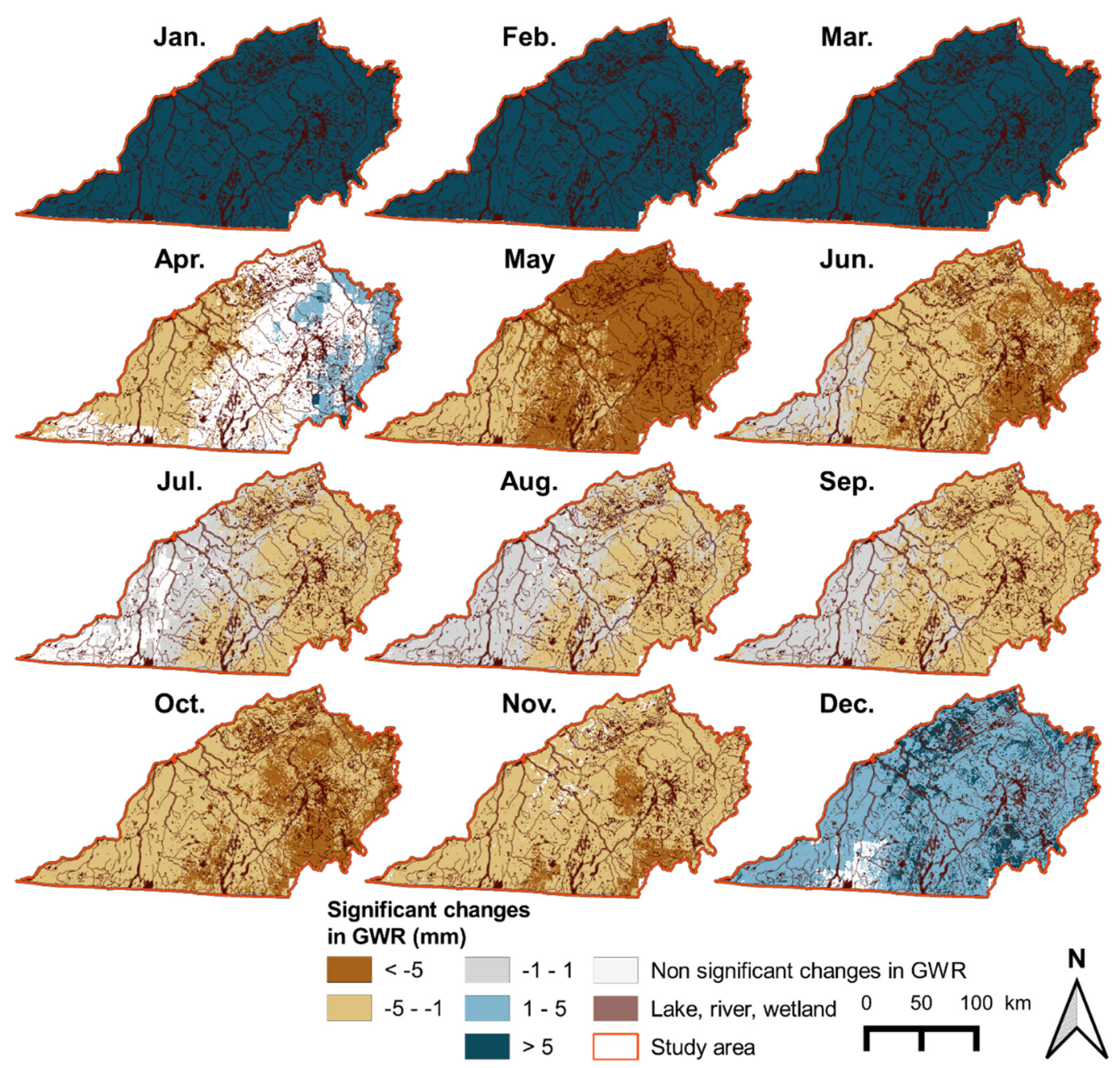

Figure 7. Spatial changes in average monthly groundwater recharge (GWR) between the reference period (1981-2010) and the 2071-2100 period for the 12 climate scenarios.

\subsection{Monthly Groundwater Recharge Changes over Time}

The watershed-scale monthly GWR for each period showed significant $\Delta \mathrm{GWR}>0$ simulated for the eight watersheds in December, January, February, and March, with significant increases from 2041-2070 to 2071-2100 from January to March (Figure 8). The range of the ensemble changes for these months also increased remarkably in the future periods in comparison to the reference period. In April, the GWR changes were smaller and the range of the ensemble was smaller. They were mainly significant in the watersheds that are partially located in the USA (W2 and W4). The future GWR in January, February, and March exceeded that of April, which exhibited a peak during the reference period. This can already be noted in the western watersheds (W1 to W4) for the 2041-2070 period and reached similar values in the eastern watersheds (W5 to W8) in March of the 2071-2100 period. Significant $\Delta G W R<0$ were simulated in May and June for the two future periods and between the two future periods for all watersheds except W1 and W2. Significant $\Delta \mathrm{GWR}<0$ were also simulated in July, August, September, and October for the eight watersheds and between the two future periods in October for the western watersheds (W5 to W8). From May to October, the range of changes of the ensemble was clearly smaller for all watersheds when comparing the reference period with the future periods. While the future GWR was close to zero as early as June and as late as October for the two most western watersheds (W1 and W2), the future GWR reached near-zero values between July and September in the other watersheds. Finally, significant $\Delta \mathrm{GWR}<0$ was simulated for 
the eight watersheds in November, again with a smaller range of changes than during the reference period.
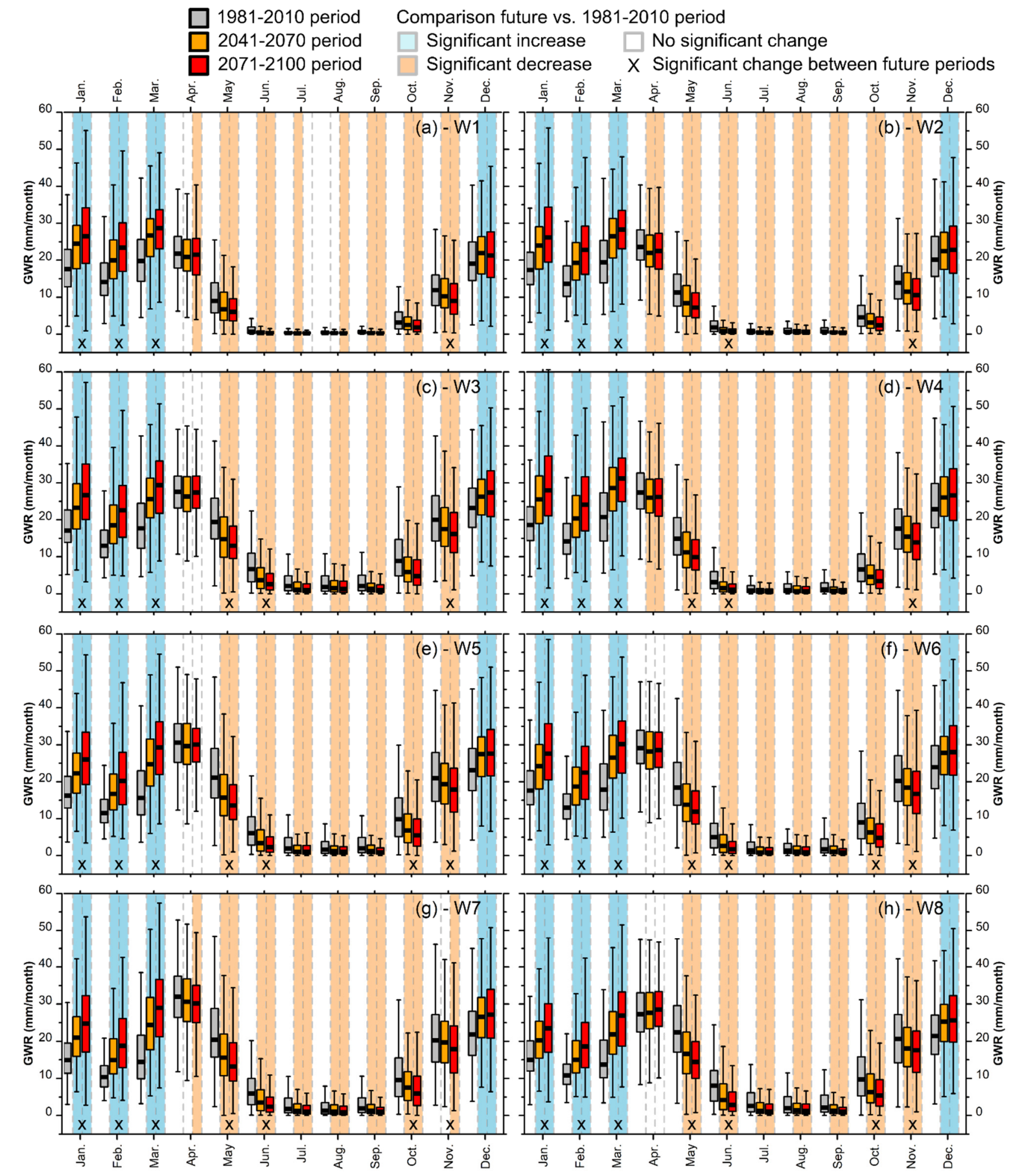

Figure 8. Monthly groundwater recharge (GWR) for the reference period (1981-2010) and the two future periods (2041-2070 and 2071-2100) for (a) W1 to (h) W8.

The sum of GWR from December to March increased by $+32 \mathrm{~mm}$ on average (mean of the ensemble of scenarios), from $+27 \mathrm{~mm}$ in $\mathrm{W} 1$ to $+36 \mathrm{~mm}$ in $\mathrm{W} 7$ and between the 
1981-2010 and 2071-2100 periods (Table 4). The sum of the GWR from May to November (months with $\mathrm{T}>0{ }^{\circ} \mathrm{C}$ ) decreased by $-19 \mathrm{~mm}$, from $-9 \mathrm{~mm}$ in $\mathrm{W} 1$ to $-26 \mathrm{~mm}$ in W8 and between the 1981-2010 and 2071-2100 periods. These seasonal changes were within the range of uncertainty of the annual GWR.

\section{Discussion}

\subsection{Future Groundwater Recharge Dynamics}

For all watersheds except W1, the GWR for the 2011-2040 period was not statistically different from that of the 1981-2010 period. Of the eight watersheds, significant GWR changes occurred with two to four climate scenarios between the 2011-2040 and 2041-2070 horizons and with four to seven climate scenarios between the 2041-2070 and 2071-2100 horizons (Figure 4). For this reason, the results were compared only between the 2041-2070 and 2071-2100 periods and the 1981-2010 period.

The simulations showed both increases and decreases in GWR in the future, hence markedly increasing the range of possible future conditions from those simulated in the reference period (Figure 4). The climate scenarios based on RCP8.5 were the wettest $(140 \mathrm{~mm}<\Delta \mathrm{P}<220 \mathrm{~mm}$, Figure 2) and thus produced increasing GWR rates in the future. Other studies have observed a wide range of hydrological responses to climate change in cold and humid regions or regions with snow-dependent hydrology $[2,11,14]$. Kurylyk and MacQuarrie [38] simulated increased future annual GWR under four climate scenarios and decreased GWR under three climate scenarios in New Brunswick (eastern Canada). Guay et al. [41] have shown, based on the simulation of future river flows in 305 watersheds in Quebec under 87 climate scenarios, that it was unclear whether future annual river flows would increase or decrease by the 2041-2070 period. Inversely, Sulis et al. [52] mainly simulated decreased future GWR in part of the Chateaugay River watershed (W1) with the integrated CATHY model for the 2041-2065 period (increase under one scenario). These authors used 12 climate scenarios based on the high-emission SRES A2 greenhouse gas projections, with annual precipitation increases of close to 0 to $+20 \%$ between the future and the reference periods. Differences in future GWR depend on the choice of future horizon and emission scenarios, as well as on the type of model used to derive the GWR [15].

The analysis of monthly recharge allowed major shifts in the intra-annual changes in future GWR to be identified. The results show that winter GWR could significantly increase due to warmer winters and lead to an earlier spring GWR peak. Other studies in eastern Canada have obtained similar results [30,33,37-39]. Similarly, Grinevskiy et al. [53] simulated GWR with an unsaturated zone model (HYDRUS-1D) in 22 sites spread over western Russia (humid climate, cold in the north, temperate in the south) and observed increased GWR during winter, which was linked to wetter and warmer winters in the North, but not in the South of the study area. Such results are reported for cold and humid climates and regions of snow-dominated hydrology with more available liquid water during winter, which is linked to warmer temperatures that affect not only GWR, but the entire hydrologic dynamic $[2,11,27,29,34,35,41,54]$. These future GWR conditions are supported by observations of past groundwater level time series showing a similar shift in the GWR peak from spring (snowmelt) to winter (rain) in Fennoscandia (Northern Europe, transition between temperate and cold climates) associated with a warming climate between the 1980-1989 and 2001-2010 periods [4].

In the present study, the GWR scenarios showed a statistically significant decrease from May to November (Figure 8). The future GWR was close to zero from July to September (similarly to the reference period), except in the western and warmest watersheds, W1 and W2, where the low flow period began a month earlier (June) and ended a month later (October). Similar results were obtained in different cold and humid climates or regions of snow-dominated hydrology. Guay et al. [41] noticed small or negligible changes in river flows during the summer, a period of the year where flow rates are already very low, extending until October. Expected dryer summer low flow rates were also reported by Addor et al. [11] and Arnoux et al. [27] for the Swiss Alps and by Dieraurer et al. [34] for 
watersheds across the Rockies (western North America), and they were linked to reduced snowpack, leading to limited snowmelt contribution to spring flows. In this study, the GWR scenarios were similar for all watersheds during summer, thus increasing the certainty of the expected summer decrease. Despite the high uncertainty in simulations of future hydrologic conditions, Addor et al. [11] reported a good convergence of results toward lower summer flow (90\% of the scenarios) for Swiss alpine watersheds, similar to that of the current study. However, Arnoux et al. [27] showed that post-glacial Quaternary deposits can contribute to the mitigation of the impact of climate change on summer low flows in alpine catchments due to their water storage capacity, which supports river low flows during long dry spells. This is an indication that water-bearing unconsolidated superficial materials could be an indicator of watershed response to climate change.

Aygün et al. [2] showed that the hydrology of cold and humid regions (northern regions of North America and Eurasia outside of the permafrost zone) with near-freezing annual temperatures were more sensitive to climate change than regions with substantially colder climates. The current study showed differences in the watershed response from west to east that followed the regional temperature gradient (decrease of mean annual temperature). These findings were most likely possible because of the use of a single model across the region and a robust knowledge of the past dynamics. Larocque et al. [15] did not find such a clear trend from west to east in their review of modeling studies of climate change impacts on groundwater systems in eastern Canada.

\subsection{Climate Changes Impacting Groundwater Recharge}

The groundwater recharge changes became statistically significant when $\triangle G W R$ was $<-15$ or $>+15 \mathrm{~mm}$ for the two future periods (Figure 5). More specifically, small GWR changes could not be interpreted as being different from the simulated variability of the 1981-2010 reference period for one to five of the 12 scenarios for the 2041-2070 period and three to six of the scenarios for the 2071-2100 period (Table 6). The increasing number of scenarios with significant changes for the 2071-2100 period is coherent with results from Goderniaux et al. [42] in the Geer Basin (Belgium), where projections of groundwater levels obtained using an ensemble of 30 climate scenarios became greater than the variability of the 1961-1990 period only in 2085. Similarly, using an ensemble of 54 climate scenarios, Addor et al. [11] demonstrated that flow rate changes in alpine catchments became significantly different from those of the 1980-2009 reference period only after the 2050 horizon. They showed that significant changes were simulated even under the climate scenarios with the lowest emissions based on RCP2.6 (not used in this study). In contrast, this study showed that climate scenarios based on RCP8.5 did not systematically produce significant changes between the future periods and the reference period, although they tended to simulate significant changes and higher future GWR than scenarios based on RCP4.5 more often. Henceforth, using a large ensemble of climate scenarios appears to be necessary to provide a representative sample of possible future precipitation and temperature.

One of the main novelties of this work lies in the identification of climate conditions leading to statistically significant changes in future GWR. Significant $\Delta G W R<0$ was simulated only with $\Delta \mathrm{P}<+150$ and $\Delta \mathrm{P}_{\mathrm{CM}}<+25 \mathrm{~mm} . \Delta \mathrm{P}<0$ always led to $\Delta \mathrm{GWR}<0$, but the latter was not necessarily significant. Inversely, $\Delta \mathrm{GWR}>0$ were significant only with $\Delta \mathrm{P}>+150$ and $\Delta \mathrm{P}_{\mathrm{CM}}>+25 \mathrm{~mm}$. Therefore, $\Delta \mathrm{P} \approx+150$ and $\Delta \mathrm{P}_{\mathrm{CM}} \approx+25 \mathrm{~mm}$ appear to be regional thresholds for determining the direction of future GWR changes.

Another contribution of this work was to determine that significant $\Delta \mathrm{GWR}<0$ was systematically associated with $\Delta \mathrm{T}$ and $\Delta \mathrm{T}_{\mathrm{CM}}$ ranging between +3 and $+5^{\circ} \mathrm{C}$, while significant $\Delta \mathrm{GWR}>0$ was found for $+2{ }^{\circ} \mathrm{C}<\Delta \mathrm{T}<+8{ }^{\circ} \mathrm{C}$ and $+3{ }^{\circ} \mathrm{C}<\Delta \mathrm{T}_{\mathrm{CM}}<+11^{\circ} \mathrm{C}$. Interestingly, $\Delta \mathrm{T}>+4.5^{\circ} \mathrm{C}$ (or $\Delta \mathrm{T}_{\mathrm{CM}}>+6{ }^{\circ} \mathrm{C}$ ) led to $\Delta \mathrm{AET}>+120 \mathrm{~mm}$, thus limiting $\Delta \mathrm{GWR}$ to $+30 \mathrm{~mm}$. Therefore, $\Delta \mathrm{T} \approx+2{ }^{\circ} \mathrm{C}$ and $\Delta \mathrm{T}_{\mathrm{CM}} \approx+3{ }^{\circ} \mathrm{C}$ appear to be regional thresholds for significant GWR changes (increase or decrease), while $\Delta \mathrm{T}>+4.5^{\circ} \mathrm{C}$ triggers GWR increase. These temperature thresholds control future GWR through the modification of the cold month 
hydrology and the evolution of ET, which also depends on the adaptation of vegetation to climate change.

This study demonstrated that, on an annual basis, $\Delta \mathrm{GWR} \mathrm{RM}_{\mathrm{C}}>+25 \mathrm{~mm}$ compensated for decreased GWR during the rest of the year and produced statistically significant $\Delta G W R>0$. This is coherent with numerous previous studies showing that the seasonality of the entire hydrologic dynamic (GWR, groundwater storage, groundwater level, stream flow) in cold and humid climates or regions of snow-dependent hydrology was affected by the increase in available liquid water during warmer winters, counterbalancing the decreasing availability of water during summer [2,4,11,27,30,35,39,41]. Rivard et al. [39] observed that changes in future GWR were most sensitive to winter temperature in simulations with a spatialized water budget model in Nova Scotia (HELP, eastern Canada, not overlapping the current study area). This was more due to increased amounts of liquid winter precipitation that was readily available for infiltration than to changes in precipitation amounts. Interestingly, Wright and Novakowski [33] showed that winter recharge events on a fractured bedrock (Ontario, Canada, frozen during winter) could bypass the frozen soil and reach unfrozen fractures at the soil/bedrock interface. They concluded that winter rainfall events could produce more GWR than during the rest of the year, thus making the precipitation form and amount during this period a sensitive GWR variable. The differences in these studies may be due to their respective scales. The local scale associated with GWR estimates based on well observations used in some studies $[4,33]$ is in dire contrast to the $250 \mathrm{~m} \times 250 \mathrm{~m}$ resolution used by Rivard et al. [39] or the $500 \mathrm{~m} \times 500 \mathrm{~m}$ in the HydroBudget model. In addition, the sub-hourly sampling time-step of other studies $[33,55]$ is not comparable to the daily time-steps aggregated into monthly inter-annual results presented here. Nevertheless, all the available studies for Eastern Canada confirm the importance of future winter GWR in the overall annual GWR dynamic, as well as the importance of capturing local-scale (meter order) processes in regional-scale GWR simulations.

From a different perspective, Sulis et al. [52] showed that changes in future GWR in a sub-watershed of W1 were linked to intra-annual patterns of the climate scenarios (more snowmelt during winter, less rain during the fall, the duration of successive days with daily precipitation $>1 \mathrm{~mm} / \mathrm{d}$ ) rather than being related to annual precipitation changes. The integrated CATHY model (daily time-step) seemed sensitive to the dryness conditions of the soil [56], thus inducing more percolation through the unsaturated zone (GWR) for climate scenarios with regular summer rainfall events than for scenarios with more intense but less frequent rainfall events. Similar conclusions were reached by Wright and Novakowski [33] at the well scale in a fractured bedrock aquifer for winter GWR events in Ontario. Finally, Rathay et al. [55] observed that increasing rainfall intensity, from $<1 \mathrm{~mm} / \mathrm{h}$ to $>1 \mathrm{~mm} / \mathrm{h}$, produced a decrease in the rainfall-groundwater level cross-correlation coefficients in a bedrock aquifer in the temperate climate of British Columbia (Canada). Although they did not identify a rainfall intensity threshold limiting GWR, these authors concluded that more intense rainfall events produced more surface and subsurface runoff rather than increasing GWR rates. Although these studies highlighted that precipitation intensity can be an important factor for future GWR changes in humid climates, the sensitivity of GWR to this parameter was not a focus of the current study.

\subsection{Future Groundwater Recharge Simulation in Cold and Humid Climates}

The clustering method used to select the subset of climate scenarios was based on ten criteria including changes in seasonal and annual precipitation, as well as changes in temperature, but did not include changes in precipitation intensity. Although recent work has projected the intensification of year-round precipitation in North America [57], precipitation intensity changes for the province of Quebec are not yet clear [25]. Further research needs to assess the impact of this variable on increasing or decreasing future GWR in cold and humid climates on intra-annual and inter-annual time scales.

Considering the range of changes in future recharge, understanding GWR under future conditions probably lies mostly in the capacity to adequately simulate GWR during the 
cold months, the period corresponding to the greatest changes in terms of absolute value in the study area. Stream flow or GWR simulations in cold and humid climates are sensitive to snow-related calibration parameters, such as the melting temperature and melting coefficient [22,58]. However, Melsen and Guse [59] showed that these parameters were less sensitive when simulating river flow in 605 USA watersheds under future conditions with decreased snowpack. Therefore, an evolution of the snow-related parameters could be expected under future conditions. Improving the simulation of winter GWR in cold regions will necessitate a better understanding of the roles of snow dynamics and soil frost in changing conditions, and future work should be aimed at calibrating these parameters for long-term regional-scale simulations.

The current study was based on the HB model, which was calibrated and validated over an exceptionally long period of time (57 years from 1961 to 2017), ensuring satisfying representativeness of the long-term and regional-scale hydrological dynamics [22]. The resulting GWR scenarios used constant model parameters over time under the hypothesis that the system was stationary in time and no significant land-use change occurred. However, Jaramillo et al. [60] linked a 40-year increase in AET rates of $65 \mathrm{~mm} / \mathrm{yr}$ in the Stockholm region (Sweden, temperate to cold climate transition zone) to land-use change, with the massive conversion of semi-natural grasslands (mowing) to cereal and fodder harvesting at the beginning of the 20th century. For Sweden as well, Destouni et al. [61] compared the evolution of evapotranspiration (ET) and runoff (R) for nine watersheds in temperate and cold climates that remained stationary in time or were affected by hydropower and non-irrigated agricultural development during the 20th century. Despite precipitation and temperature increases, they found that ET and R remained stable in unregulated watersheds, while hydropower development increased ET and decreased R, and agriculture development increased both ET and R. These hydrological changes impact the regional water budget, and therefore most likely propagate to GWR. Alternatively, Guerrero-Morales et al. [62] found that land cover changes accounted for $25 \%$ of the GWR decrease in an urbanized watershed in western Mexico (warm and humid climate) under climate change conditions by the 2050 horizon. Although Kløve et al. [9] and Taylor et al. [10] stated that climate change studies should consider land-use change, integrating land-use scenarios into future GWR simulations in cold and humid climates has not been widely reported in the scientific literature. Further study of this important question could lead to the identification of other factors than climate that determine the extent of possible GWR changes. Considering land-use change would also probably increase the uncertainty of future GWR simulations [63].

Reinecke et al. [17] concluded on the importance of coupling biosphere dynamic simulations to long-term GWR simulation, especially at the global scale, where increases in atmospheric $\mathrm{CO}_{2}$ concentrations could lead to more active vegetation, which would, in turn, impact GWR estimates. Koirala et al. [64] showed that vegetation had a large impact on the water budget through AET, especially in humid climates. To avoid using scenarios of future solar radiation and other climate variables that are less readily available, more difficult to bias-correct, and may introduce additional uncertainty compared to the more common temperature and precipitation scenarios [25], the maximum daily ET in HB was based on the simple formula from Oudin et al. [47], which only used daily temperature, latitude, and Julian day (as a proxy for extraterrestrial radiation). However, considering the regional scale of the study and the long-term simulation period, more work should be dedicated to improving AET simulations for cold and humid climates, especially considering the uncertainty related to plant adaptation to warmer climates. This could impact the temperature thresholds identified in this study. Specific AET calibration could be developed using spatialized time-series of the measured AET, or the impact of coupling biosphere dynamics and GWR at the regional scale could be tested. 


\subsection{Using These Results for Adaptation}

Studies clearly show that GWR in cold and humid climates could follow different paths of change depending on specific climate conditions, geology, morphology, and land use $[15,38]$. Taking into consideration uncertainty in future climate conditions is another major challenge, as this study showed with future GWR that can either increase or decrease at the regional scale depending on the climate scenario It is thus extremely difficult to provide concrete recommendations to water managers despite the increasing body of knowledge [14].

Nevertheless, several patterns in the future evolution of GWR emerged with a relatively high level of confidence. For example, the significant projected decrease in GWR from May to November as soon as the 2041-2070 period and the substantial increase in GWR from December to March clearly stand out. A cold month GWR increase of $>+25$ mm will compensate for the decrease throughout the rest of the year, suggesting stable groundwater resources. Additionally, this work provides threshold values for changes in precipitation and temperature that lead to likely increases or decreases in future GWR (Figure 9). These thresholds could be used in integrated water resource management plans, where they could trigger specific actions (e.g., if local warming reaches $1.5,2$, or $3{ }^{\circ} \mathrm{C}$, associated with stable precipitation increase of +50 or $+100 \mathrm{~mm})$. Although they would probably be similar in other cold and humid climates in post-glacial geological environments, these thresholds will need to be tested in different contexts.

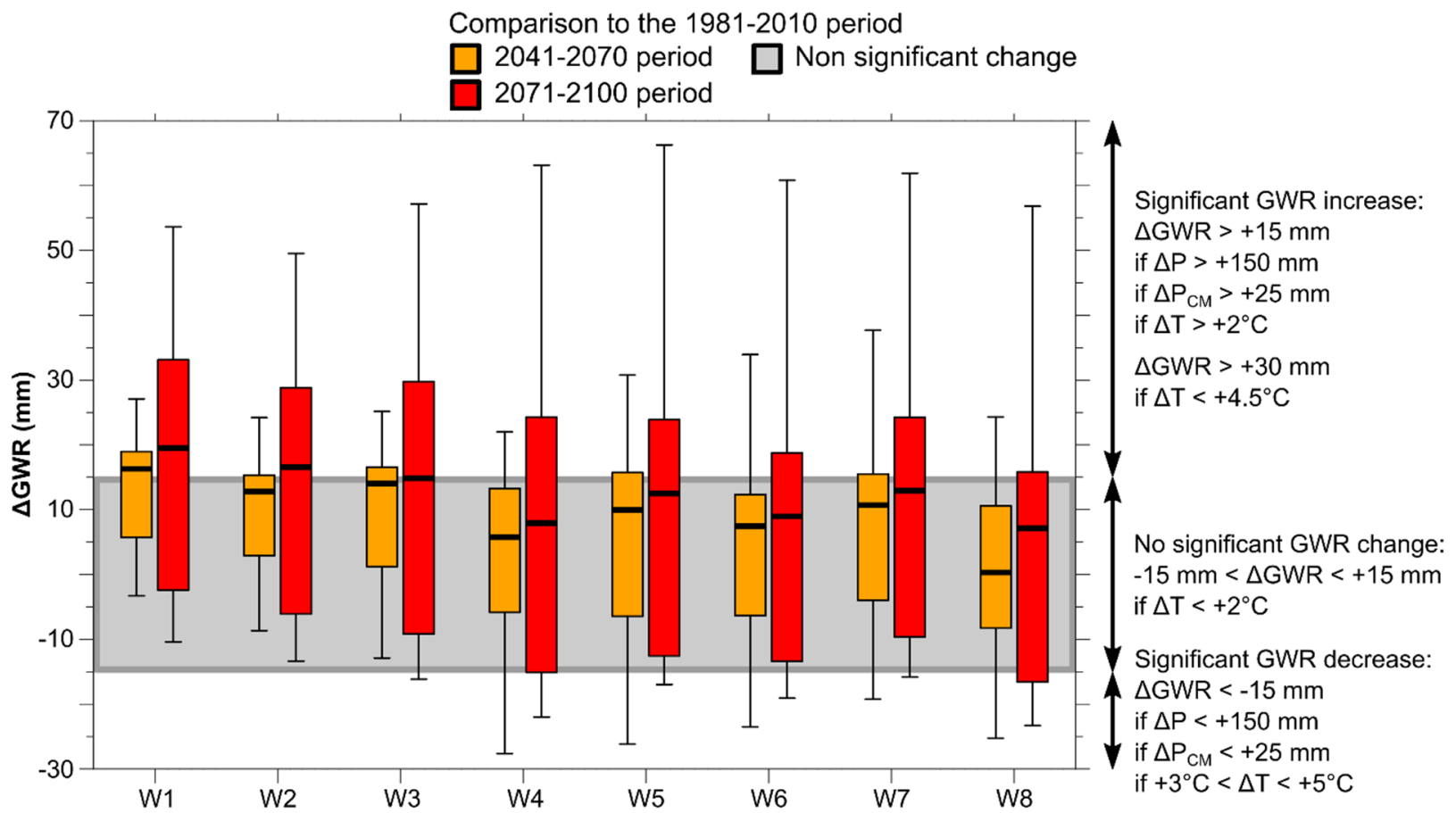

Figure 9. Annual groundwater recharge changes $(\Delta G W R)$ between the reference period (1981-2010) and future periods (2041-2070 and 2071-2100) for the eight watersheds (W1-W8) and 12 scenarios. The associated precipitation and temperature thresholds are displayed on the right, and the gray zone indicates the -15 to $+15 \mathrm{~mm}$ non-significant change range in GWR. CM stands for cold months (December to March).

In cold and humid climates, GWR generally represents the actual aquifer renewal rates-the total flow discharging to superficial water bodies $[4,19,21]$. A decrease in future GWR from May to November means that groundwater inflow into superficial water bodies and groundwater levels will decrease when water demand for drinking water, agriculture, industrial purposes, hydroelectricity, and recreation is the highest $[19,65]$ and when river flows come almost exclusively from a connected aquifer. Considering the high confidence 
in the simulation of the decreasing GWR from May to November, it is expected that water use conflicts will increase in future decades.

The identified thresholds were related to potential GWR, i.e., the maximum GWR that can reach the saturated zone [22]. Future changes in actual GWR are expected to be closely linked to those in potential GWR. For scenarios and periods where potential GWR is expected to decrease, actual GWR will most likely decrease as well due to the reduction of available water. Inversely, for expected increases in potential GWR, actual GWR changes would vary depending on the AET rates. Future work studying the propagation of these changes should focus on the periods of expected potential GWR increases.

\section{Conclusions}

In cold and humid climates, the impact of climate change will propagate in groundwater systems and more broadly to regional hydrologic dynamics through GWR. Estimates of changes in GWR under future climate conditions are therefore strategic for long-term water resource management. This work has provided new data for assessing climate change impacts on GWR and to identify controlling processes and thresholds for cold and humid climates. One of the outcomes was the simulation of the first set of 12 transient regionalscale GWR scenarios for the 1951-2100 period in southern Quebec. Simulated using a water budget model and a set of 12 climate scenarios maximizing the future climate variability (12 GCMs using RCP4.5 and RCP8.5), the spatio-temporal GWR scenarios showed notable changes occurring in the 2041-2070 and 2071-2100 periods. Warming temperatures were between +1 and $+5{ }^{\circ} \mathrm{C}$ at the 2041-2070 horizon (in comparison with the 1981-2010 reference period), and the precipitation change pattern was more variable, including an increase of $+10 \%$ to $+80 \%$ in the available liquid water between March and December. Increasing and decreasing annual GWR was simulated. However, major impacts were found in the monthly dynamics, with a statistically significant decrease in future GWR from May to November compensated by a statistically significant increase in future GWR from December to March. The periods of null or very low GWR rates were lengthened by one month in June and October for the warmer watersheds. Overall, the average annual GWR change was positive if the increase in future cold month GWR was higher than $+25 \mathrm{~mm}$, offsetting the decrease for the rest of the year. Such results were coherent with previous findings in other regions of cold and humid climates.

The novelty of this work lies in linking changing climate conditions to the direction and amplitude of statistically significant changes in future regional GWR through specific precipitation and temperature change thresholds. All significant changes in GWR were $>+15$ or $<-15 \mathrm{~mm} / \mathrm{yr}$ and were only produced by warming temperatures $>+2{ }^{\circ} \mathrm{C}$. A significant decrease in future GWR was always simulated under future increases in annual precipitation of $<+150 \mathrm{~mm}$ and cold month precipitation changes of $<+25 \mathrm{~mm}$, along with warming temperatures of between +3 and $+5{ }^{\circ} \mathrm{C}$ (for annual and cold months). A significant increase in future GWR was systematically simulated under increases in annual precipitation of $>+150 \mathrm{~mm}$ and cold month precipitation increases of $>+25 \mathrm{~mm}$, along with warming temperatures of $>+2{ }^{\circ} \mathrm{C}$. A future temperature increase of $>+4.5^{\circ} \mathrm{C}$ produced more intense AET rates, thus limiting the increase in future GWR to approximately $+30 \mathrm{~mm}$, irrespective of the precipitation increase. These thresholds are sufficiently straightforward for general use and for integrated water resource management plans.

Author Contributions: All authors contributed to writing the manuscript. E.D., M.L., and S.G. developed the approach. M.B. selected climate scenarios through cluster analysis. Simulations and figure preparation were done by E.D., M.L. obtained the research grant and supervised the research. All authors have read and agreed to the published version of the manuscript.

Funding: This research was funded by the Quebec Ministry of Environment and Climate Change (Ministère de l'Environnement et de la Lutte contre les changements climatiques).

Institutional Review Board Statement: Not applicable. 
Informed Consent Statement: Not applicable.

Data Availability Statement: The simulated scenarios presented in this work are available here: https:/ / doi.org/10.5683/SP3/SWH4O1.

Acknowledgments: The authors are grateful to the Ouranos Consortium for providing downscaled climate scenarios and acknowledge the model output data from the World Climate Research Programme's Coupled Modelling Intercomparison Project Phase 5 (CMIP5) as well as the gridded observation data made available by Natural Resources Canada's (NRCan).

Conflicts of Interest: The authors declare no conflict of interest. The funders had no role in the design of the study; in the collection, analyses, or interpretation of data; in the writing of the manuscript, or in the decision to publish the results.

\section{References}

1. Gudmundsson, L.; Boulange, J.; Do, H.X.; Gosling, S.N.; Grillakis, M.G.; Koutroulis, A.G.; Leonard, M.; Liu, J.; Schmied, H.M.; Papadimitriou, L.; et al. Globally observed trends in mean and extreme river flow attributed to climate change. Science 2021, 371 1159-1162. [CrossRef]

2. Aygün, O.; Kinnard, C.; Campeau, S. Impacts of climate change on the hydrology of northern midlatitude cold regions. Prog. Phys. Geogr. Earth Environ. 2019, 44, 338-375. [CrossRef]

3. Lee, B.; Hamm, S.-Y.; Jang, S.; Cheong, J.-Y.; Kim, G.-B. Relationship between groundwater and climate change in South Korea. Geosci. J. 2013, 18, 209-218. [CrossRef]

4. $\quad$ Nygren, M.; Giese, M.; Kløve, B.; Haaf, E.; Rossi, P.M.; Barthel, R. Changes in seasonality of groundwater level fluctuations in a temperate-cold climate transition zone. J. Hydrol. X 2020, 8, 100062. [CrossRef]

5. Arctic Climate Impact Assessment. Impacts of a Warming Arctic; Cambridge University Press: Cambridge, UK; New York, NY, USA, 2004; ISBN 978-0-521-61778-9.

6. Döll, P. Vulnerability to the impact of climate change on renewable groundwater resources: A global-scale assessment. Environ. Res. Lett. 2009, 4, 035006. [CrossRef]

7. Döll, P.; Trautmann, T.; Gerten, D.; Schmied, H.M.; Ostberg, S.; Saaed, F.; Schleussner, C.-F. Risks for the global freshwater system at $1.5^{\circ} \mathrm{C}$ and $2{ }^{\circ} \mathrm{C}$ global warming. Environ. Res. Lett. 2018, 13, 044038. [CrossRef]

8. Green, T.R.; Taniguchi, M.; Kooi, H.; Gurdak, J.J.; Allen, D.M.; Hiscock, K.M.; Treidel, H.; Aureli, A. Beneath the surface of global change: Impacts of climate change on groundwater. J. Hydrol. 2011, 405, 532-560. [CrossRef]

9. Klöve, B.; Ala-Aho, P.; Bertrand, G.; Gurdak, J.J.; Kupfersberger, H.; Kværner, J.; Muotka, T.; Mykrä, H.; Preda, E.; Rossi, P.M.; et al. Climate change impacts on groundwater and dependent ecosystems. J. Hydrol. 2014, 518, 250-266. [CrossRef]

10. Taylor, R.G.; Scanlon, B.; Döll, P.; Rodell, M.; Van Beek, R.; Wada, Y.; Longuevergne, L.; Leblanc, M.; Famiglietti, J.S.; Edmunds, M.; et al. Ground water and climate change. Nat. Clim. Chang. 2013, 3, 322-329. [CrossRef]

11. Addor, N.; Rössler, O.; Köplin, N.; Huss, M.; Weingartner, R.; Seibert, J. Robust changes and sources of uncertainty in the projected hydrological regimes of Swiss catchments. Water Resour. Res. 2014, 50, 7541-7562. [CrossRef]

12. Allen, D.M.; Cannon, A.; Toews, M.; Scibek, J. Variability in simulated recharge using different GCMs. Water Resour. Res. 2010, 46, W00F03. [CrossRef]

13. Crosbie, R.S.; Pickett, T.; Mpelasoka, F.S.; Hodgson, G.; Charles, S.P.; Barron, O.V. An assessment of the climate change impacts on groundwater recharge at a continental scale using a probabilistic approach with an ensemble of GCMs. Clim. Chang. 2012, 117, 41-53. [CrossRef]

14. Smerdon, B.D. A synopsis of climate change effects on groundwater recharge. J. Hydrol. 2017, 555, 125-128. [CrossRef]

15. Larocque, M.; Levison, J.; Martin, A.; Chaumont, D. A review of simulated climate change impacts on groundwater resources in Eastern Canada. Can. Water Resour. J. Rev. Can. Des Ressour. Hydr. 2019, 44, 22-41. [CrossRef]

16. Moeck, C.; Brunner, P.; Hunkeler, D. The influence of model structure on groundwater recharge rates in climate-change impact studies. Hydrogeol. J. 2016, 24, 1171-1184. [CrossRef]

17. Reinecke, R.; Schmied, H.M.; Trautmann, T.; Andersen, L.S.; Burek, P.; Flörke, M.; Gosling, S.N.; Grillakis, M.; Hanasaki, N.; Koutroulis, A.; et al. Uncertainty of simulated groundwater recharge at different global warming levels: A global-scale multi-model ensemble study. Hydrol. Earth Syst. Sci. 2021, 25, 787-810. [CrossRef]

18. Gleeson, T.; Marklund, L.; Smith, L.; Manning, A. Classifying the water table at regional to continental scales. Geophys. Res. Lett. 2011, 38, L05401. [CrossRef]

19. Kløve, B.; Kvitsand, H.M.L.; Pitkänen, T.; Gunnarsdottir, M.J.; Gaut, S.; Gardarsson, S.; Rossi, P.M.; Miettinen, I. Overview of groundwater sources and water-supply systems, and associated microbial pollution, in Finland, Norway and Iceland. Appl. Hydrogeol. 2017, 25, 1033-1044. [CrossRef]

20. Meyzonnat, G.; Barbecot, F.; Alazard, M.; McCormack, R. La Richesse de La Ressource En Eau Du Québec (Richness of Quebec's Water Ressource). Géologues Rev. Off. Société Géologique Fr. 2018, 198, 69-75.

21. Rivera, A. Canada's Groundwater Resources; Fitzhenry \& Whiteside: Markham, ON, Canada, 2014; ISBN 978-1-55455-292-4. 
22. Dubois, E.; Larocque, M.; Gagné, S.; Meyzonnat, G. Simulation of long-term spatiotemporal variations in regional-scale groundwater recharge: Contributions of a water budget approach in cold and humid climates. Hydrol. Earth Syst. Sci. 2021, 25, 6567-6589. [CrossRef]

23. Cuthbert, M.O.; Gleeson, T.; Moosdorf, N.; Befus, K.M.; Schneider, A.; Hartmann, J.; Lehner, B. Global patterns and dynamics of climate-groundwater interactions. Nat. Clim. Chang. 2019, 9, 137-141. [CrossRef]

24. Collins, M.; Knutti, R.; Arblaster, J.; Dufresne, J.-L.; Fichefet, T.; Friedlingstein, P.; Gao, X.; Gutowski, W.J.; Johns, T.; Krinner, G.; et al. Long-term Climate Change: Projections, Commitments and Irreversibility. In Climate Change 2013: The Physical Science Basis. Contribution of Working Group I to the Fifth Assessment Report of the Intergovernmental Panel on Climate Change; Stocker, T.F., Qin, D., Plattner, G.-K., Tignor, M., Allen, S.K., Boschung, J., Nauels, A., Xia, Y., Bex, V., Midgley, P.M., Eds.; Cambridge University Press: Cambridge, UK; New York, NY, USA, 2013; pp. 1029-1136. ISBN 978-1-107-66182-0.

25. Ouranos. Vers l'adaptation-Synthèse Des Connaissances Sur Les Changements Climatiques Au Québec. (Toward Adaptation-Synthesis on the Knowledge about Climate Change in Quebec), 2015 ed.; Ouranos: Montréal, QC, Canada, 2015; ISBN 978-2-923292-18-2.

26. Vincent, L.; Zhang, X.; Mekis, E.; Wan, H.; Bush, E. Changes in Canada's Climate: Trends in Indices Based on Daily Temperature and Precipitation Data. Atmosphere-Ocean 2018, 56, 332-349. [CrossRef]

27. Arnoux, M.; Brunner, P.; Schaefli, B.; Mott, R.; Cochand, F.; Hunkeler, D. Low-flow behavior of alpine catchments with varying quaternary cover under current and future climatic conditions. J. Hydrol. 2021, 592, 125591. [CrossRef]

28. Barnett, T.P.; Adam, J.C.; Lettenmaier, D.P. Potential impacts of a warming climate on water availability in snow-dominated regions. Nature 2005, 438, 303-309. [CrossRef] [PubMed]

29. Berghuijs, W.R.; Woods, R.A.; Hrachowitz, M. A precipitation shift from snow towards rain leads to a decrease in streamflow. Nat. Clim. Chang. 2014, 4, 583-586. [CrossRef]

30. Cochand, F.; Therrien, R.; Lemieux, J.-M. Integrated Hydrological Modeling of Climate Change Impacts in a Snow-Influenced Catchment. Groundwater 2018, 57, 3-20. [CrossRef]

31. Hayashi, M.; Farrow, C.R. Watershed-scale response of groundwater recharge to inter-annual and inter-decadal variability in precipitation (Alberta, Canada). Hydrogeol. J. 2014, 22, 1825-1839. [CrossRef]

32. Scibek, J.; Allen, D.M.; Cannon, A.; Whitfield, P. Groundwater-surface water interaction under scenarios of climate change using a high-resolution transient groundwater model. J. Hydrol. 2007, 333, 165-181. [CrossRef]

33. Wright, S.N.; Novakowski, K.S. Impacts of warming winters on recharge in a seasonally frozen bedrock aquifer. J. Hydrol. 2020, 590, 125352. [CrossRef]

34. Dierauer, J.R.; Whitfield, P.H.; Allen, D.M. Climate Controls on Runoff and Low Flows in Mountain Catchments of Western North America. Water Resour. Res. 2018, 54, 7495-7510. [CrossRef]

35. Jenicek, M.; Seibert, J.; Zappa, M.; Staudinger, M.; Jonas, T. Importance of maximum snow accumulation for summer low flows in humid catchments. Hydrol. Earth Syst. Sci. 2016, 20, 859-874. [CrossRef]

36. Kong, Y.; Wang, C.-H. Responses and changes in the permafrost and snow water equivalent in the Northern Hemisphere under a scenario of $1.5^{\circ} \mathrm{C}$ warming. Adv. Clim. Chang. Res. 2017, 8, 235-244. [CrossRef]

37. Jyrkama, M.I.; Sykes, J.F. The impact of climate change on spatially varying groundwater recharge in the grand river watershed (Ontario). J. Hydrol. 2007, 338, 237-250. [CrossRef]

38. Kurylyk, B.L.; MacQuarrie, K.T. The uncertainty associated with estimating future groundwater recharge: A summary of recent research and an example from a small unconfined aquifer in a northern humid-continental climate. J. Hydrol. 2013 , 492, $244-253$. [CrossRef]

39. Rivard, C.; Paniconi, C.; Vigneault, H.; Chaumont, D. A watershed-scale study of climate change impacts on groundwater recharge (Annapolis Valley, Nova Scotia, Canada). Hydrol. Sci. J. 2014, 59, 1437-1456. [CrossRef]

40. Direction De L'expertise Hydrique (DEH) Atlas Hydroclimatique Du Québec Méridional (Hydroclimatic Atlas of Southern Quebec). Available online: https://www.cehq.gouv.qc.ca/atlas-hydroclimatique/Hydraulicite/Qmoy.htm (accessed on 13 April 2021).

41. Guay, C.; Minville, M.; Braun, M. A global portrait of hydrological changes at the 2050 horizon for the province of Québec. Can. Water Resour. J. Rev. Can. Des Ressour. Hydr. 2015, 40, 285-302. [CrossRef]

42. Goderniaux, P.; Brouyère, S.; Blenkinsop, S.; Burton, A.; Fowler, H.; Orban, P.; Dassargues, A. Modeling climate change impacts on groundwater resources using transient stochastic climatic scenarios. Water Resour. Res. 2011, 47, W12516. [CrossRef]

43. Hund, S.V.; Allen, D.M.; Morillas, L.; Johnson, M.S. Groundwater recharge indicator as tool for decision makers to increase socio-hydrological resilience to seasonal drought. J. Hydrol. 2018, 563, 1119-1134. [CrossRef]

44. Bertrand, G.; Ponçot, A.; Pohl, B.; Lhosmot, A.; Steinmann, M.; Johannet, A.; Pinel, S.; Caldirak, H.; Artigue, G.; Binet, P.; et al. Statistical hydrology for evaluating peatland water table sensitivity to simple environmental variables and climate changes application to the mid-latitude/altitude Frasne peatland (Jura Mountains, France). Sci. Total. Environ. 2020, 754, 141931. [CrossRef]

45. Dubois, E.; Larocque, M.; Gagné, S.; Meyzonnat, G. HydroBudget User Guide: Version 1.2; Université du Québec à Montréal, Département des sciences de la Terre et de l'atmosphère: Montréal, QC, Canada, 2021; Available online: https://archipel.uqam. ca/14075/ (accessed on 14 November 2021).

46. Dubois, E.; Larocque, M.; Gagne, S.; Meyzonnat, G. HydroBudget-Groundwater Recharge Model in R. Dataverse [Code]. 2021. Available online: https:/ / doi.org/10.5683/SP3/EUDV3H (accessed on 14 November 2021). 
47. Oudin, L.; Hervieu, F.; Michel, C.; Perrin, C.; Andréassian, V.; Anctil, F.; Loumagne, C. Which potential evapotranspiration input for a lumped rainfall-runoff model? Part 2-Towards a simple and efficient potential evapotranspiration model for rainfall-runoff modelling. J. Hydrol. 2005, 303, 290-306. [CrossRef]

48. Casajus, N.; Perie, C.; Logan, T.; Lambert, M.-C.; De Blois, S.; Berteaux, D. An Objective Approach to Select Climate Scenarios when Projecting Species Distribution under Climate Change. PLoS ONE 2016, 11, e0152495. [CrossRef]

49. Hopkinson, R.F.; McKenney, D.W.; Milewska, E.J.; Hutchinson, M.F.; Papadopol, P.; Vincent, L.A. Impact of Aligning Climatological Day on Gridding Daily Maximum-Minimum Temperature and Precipitation over Canada. J. Appl. Meteorol. Clim. 2011, 50, 1654-1665. [CrossRef]

50. Hutchinson, M.F.; McKenney, D.W.; Lawrence, K.; Pedlar, J.H.; Hopkinson, R.F.; Milewska, E.; Papadopol, P. Development and Testing of Canada-Wide Interpolated Spatial Models of Daily Minimum-Maximum Temperature and Precipitation for 1961-2003. J. Appl. Meteorol. Clim. 2009, 48, 725-741. [CrossRef]

51. Mpelasoka, F.S.; Chiew, F.H.S. Influence of Rainfall Scenario Construction Methods on Runoff Projections. J. Hydrometeorol. 2009, 10, 1168-1183. [CrossRef]

52. Sulis, M.; Paniconi, C.; Marrocu, M.; Huard, D.; Chaumont, D. Hydrologic response to multimodel climate output using a physically based model of groundwater/surface water interactions. Water Resour. Res. 2012, 48, W12510. [CrossRef]

53. Grinevskiy, S.; Pozdniakov, S.; Dedulina, E. Regional-Scale Model Analysis of Climate Changes Impact on the Water Budget of the Critical Zone and Groundwater Recharge in the European Part of Russia. Water 2021, 13, 428. [CrossRef]

54. Luoma, S.; Okkonen, J. Impacts of Future Climate Change and Baltic Sea Level Rise on Groundwater Recharge, Groundwater Levels, and Surface Leakage in the Hanko Aquifer in Southern Finland. Water 2014, 6, 3671-3700. [CrossRef]

55. Rathay, S.; Allen, D.; Kirste, D. Response of a fractured bedrock aquifer to recharge from heavy rainfall events. J. Hydrol. 2018, 561, 1048-1062. [CrossRef]

56. Sulis, M.; Paniconi, C.; Rivard, C.; Harvey, R.; Chaumont, D. Assessment of climate change impacts at the catchment scale with a detailed hydrological model of surface-subsurface interactions and comparison with a land surface model. Water Resour. Res. 2011, 47, W01513. [CrossRef]

57. Prein, A.F.; Rasmussen, R.M.; Ikeda, K.; Liu, C.; Clark, M.P.; Holland, G.J. The future intensification of hourly precipitation extremes. Nat. Clim. Chang. 2016, 7, 48-52. [CrossRef]

58. Nemri, S.; Kinnard, C. Comparing calibration strategies of a conceptual snow hydrology model and their impact on model performance and parameter identifiability. J. Hydrol. 2019, 582, 124474. [CrossRef]

59. Melsen, L.A.; Guse, B. Climate change impacts model parameter sensitivity-Implications for calibration strategy and model diagnostic evaluation. Hydrol. Earth Syst. Sci. 2021, 25, 1307-1332. [CrossRef]

60. Jaramillo, F.; Prieto, C.; Lyon, S.W.; Destouni, G. Multimethod assessment of evapotranspiration shifts due to non-irrigated agricultural development in Sweden. J. Hydrol. 2013, 484, 55-62. [CrossRef]

61. Destouni, G.; Jaramillo, F.; Prieto, C. Hydroclimatic shifts driven by human water use for food and energy production. Nat. Clim. Chang. 2012, 3, 213-217. [CrossRef]

62. Guerrero-Morales, J.; Fonseca, C.; Goméz-Albores, M.; Sampedro-Rosas, M.; Silva-Gómez, S. Proportional Variation of Potential Groundwater Recharge as a Result of Climate Change and Land-Use: A Study Case in Mexico. Land 2020, 9, 364. [CrossRef]

63. Verburg, P.H.; Neumann, K.; Nol, L. Challenges in using land use and land cover data for global change studies. Glob. Chang. Biol. 2011, 17, 974-989. [CrossRef]

64. Koirala, S.; Jung, M.; Reichstein, M.; De Graaf, I.; Camps-Valls, G.; Ichii, K.; Papale, D.; Ráduly, B.; Schwalm, C.R.; Tramontana, G.; et al. Global distribution of groundwater-vegetation spatial covariation. Geophys. Res. Lett. 2017, 44, 4134-4142. [CrossRef]

65. Groupe Agéco. Recherche Participative D'alternatives Durables Pour La Gestion De L'eau En Milieu Agricole Dans Un Contexte De Changement Climatique (RADEAU1) (Participative Research for Sustainable Options in Water Management in Agricole Region and within a Climate Change Context); Ministère de l'agriculture, des pêcheries et de l'alimentation, Fonds Vert: Quebec City, QC, Canada, 2019; p. 332. Available online: https:/ / www.agrireseau.net/documents/Document_101346.pdf (accessed on 14 November 2021). 